Тильман Бергер

Тюбингенский университет

Институт славистики

tberger@uni-tuebingen.de

\section{Бьёрн Вимер}

Университет Яна Гутенберга, Майнц Институт славистики, тюркологии и циркумбалтийских исследований wiemerb@uni-mainz.de
УДК 811.162.1'367.332.7'367.633:811.162.3'367.332.7'367.633 https://doi.org/10.18485/slavistika.2018.22.1.2 оригинални научни рад примљено 12.03.2018

прихваћено за штампу 11.04.2018

\title{
ПРЕДЛОЖНЫЙ РЕЗУЛЬТАТИВ В ПОЛЬСКОМ И ЧЕШСКОМ ЯЗЫКАХ
}

Статья посвящена специфической результативной конструкции, которая особенно характерна для польского и чешского языков. В этой предикативной конструкции связка (пол. być, чеш. být) сочетается с составляемой, вершина которой является предлог ро 'после' во временно́м значении. Конструкцию можно причислить к результативным, так как описываемое ею состояние имплицитно предполагает предельное событие, результатом которого это состояние является. Особенность конструкции в том, что она не уточняет содержание состояния. Конструкции можно приписать три разных значения, и она выступает в двух синтаксических вариантах - одном личном (с подлежащим) и одном безличном (без подлежащего). Основной анализ этих вариантов проводится на данных из четырех электронных корпусов. Выделяются сходства и различия между польским и чешским языками, причем особое внимание уделяется фактам распределения вариантов и значений в зависимости от их лексического заполнения. В частности, можно показать, что безличный вариант в обоих языках примерно одинаково продуктивен, в то время как личный вариант в польском языке намного продуктивнее, чем в чешском. Тем самым анализ показывает, что для изучения свойств, связанных с распределением грамматических конструкций и их продуктивности, работа с корпусами незаменима.

Ключевые слова: результатив, польский язык, чешский язык, предложные группы, импликатуры, метонимические сдвиги, распределение, лексическое заполнение, электронные корпуса.

The article examines a specific resultative construction, particularly characteristic for Polish and Czech. This predicative construction is composed of a copula (Pol. być, Czech být) and a phrase headed by the temporal preposition $p o$ 'after'. It can be considered resultative because it describes a state which implies a telic event causing this state. The construction is peculiar inasmuch as it does not specify the concrete type of state. It can be ascribed three different meanings distributed over two syntactic variants - one containing a nominatival subject, the other occurring without a subject. Our analysis is based mainly on data from four electronic corpora. We point out convergent and divergent features of Polish and Czech, focusing on facts of distribution and observable lexical input to the construction. Our analysis reveals that in both languages the subjectless variant shows more or less identical productivity, while the variant with a subject is much more productive in Polish than it is in Czech. By the same token, our analysis demonstrates that properties related to the distribution and productivity of grammatical constructions can only be explored on the basis of corpora.

Key words: resultative, Polish, Czech, prepositional phrases, implicatures, metonymical shifts, distribution, lexical input, electronic corpora.

Славистика XXII/1 (2018) 


\section{§1.Введение}

В статье речь пойдет главным образом о своеобразной предикативной конструкции, которая бросается в глаза в чешском и польском языках. Ее внешний облик очень простой:

$$
\mathrm{ESSE}+p o+\mathrm{NOUN}_{\mathrm{LOC}} \text {. }
$$

Важно подчеркнуть, что эту конструкцию мы рассматриваем только в функции основного предиката (сказуемого) предложения. В качестве обстоятельств обороты с предлогом ро во временно́м значении тривиальны и широко распространены. То же самое верно относительно их соответствий в других славянских языках, напр. с предлогами типа рус. после. Следует подчеркнуть, что в предикативном употреблении интересующий нас оборот в большей части славянских языков представлен намного у́же. Обращает он на себя внимание в западнославянских языках; за их пределами конструкция (1) либо отсутствует, либо наблюдается намного реже. Видимо, за пределами западнославянского ареала эта предикативная конструкция подлежит жестким ограничениям как по сфере применения, так и в плане лексического заполнения (см. §2.2.2). Это утверждение можно расширить на временные предложные обороты в неславянских языках, хотя бы Европы (см. §2.1).

В западнославянских языках конструкция осуществляется в двух синтаксических вариантах. Личный вариант, т.е. с подлежащим в именительном падеже, представлен во всей этой группе (2), тогда как безличный вариант, т.е. без подлежащего, наблюдается во всех этих языках; правда, его употребление в верхнелужицком (3) несколько более ограничено (см. §2.2.1.4).

личный вариант ${ }^{1}$

(2а) польский

(2б) чешский

(2в) словацкий

(2г) верхнелужицкий
Już jestem po śniadaniu.

'Я уже (по)завтракал.'

Déti jsou po snídani.

'Дети уже (по)завтракали.'

V̌setci už boli po obede.

'Все уже отобедали [были пообедавши].'

Janina bě hižo po jědźi.

'Янина уже поела [после еды].'

${ }^{1}$ Следует оговориться, что специфическая семантика рассматриваемой конструкции в русском языке передается с трудом или лишь искаженно. Поэтому большинство переводов останется в большей или меньшей мере неадекватным, а читателю они послужат лишь грубым ориентиром. 
безличный вариант

(3a) польский

(3б) чешский

(3в) словацкий

(3г) верхнелужицкий
Już jest po wszystkim / po sprawie / po ptakach. Už je po všem / po problému / po ptákách.

Už je po všetkom / po problému / po vtákoch.

'Уже все позади.'

Bórze budźe po straše. (цит. по Faska 2009: 200)

'Скоро испуг пройдет.'

Эти предложные обороты указывают на предшествование какой-нибудь одной ситуации $\mathrm{C}_{1}$ непосредственно примыкающей за ней ситуации $\mathrm{C}_{2}$ : 'после $\mathrm{C}_{1}$ началась ситуация $\mathrm{C}_{2}$ ', причем $\mathrm{C}_{1}$ называется существительным, которым управляет предлог. Интерпретация следования возникает от того, что в коммуникативном фокусе находится $\mathrm{C}_{2}, \mathrm{a}_{1}$ уступает в фон. Изучаемую конструкцию мы условно называем «предложным результативом», потому что в грубом приближении ее смысл сводится к указанию на состояние, наступившее после некоторой смены вследствие событий, связанных с референтом, который называет существительное управляемое предлогом ро 'после' (точнее см. в §3). Эта общая характеристика роднит рассматриваемую нами предикативную конструкцию с разнородными типами результативных конструкций, хорошо представленных в разных языках мира и часто дающих начало перфектам. ${ }^{2}$ Наша цель не только в том, чтобы описать эту западнославянскую конструкцию, но и сделать возможным ее сопоставление с другими результативными конструкциями. Это включает обсуждение ее грамматического статуса, взаимодействие с лексикой (т.е. с существительными, способными занимать место, управляемое предлодгом ро) и свойства распределения ее вариантов, которые мы выделим ниже.

Насколько нам известно, настоящая статья является первой попыткой описания предложного результатива. По нашим сведениям, практически никто не проводил исследования по этой предикативной конструкции, в литературе можно найти о ней лишь случайные упоминания, которые затрагивают только отдельные ее грамматические или прагматические свойства. Ввиду ареально довольно четко ограниченного распространения этой конструкции и ввиду богатой литературы по результативным конструкциям такое состояние дел вызывает удивление. Поэтому мы в этой статье сначала совершим обзор работ, в которых вообще о конструкциях типа (1) упоминается (§2), прежде чем приступать к определению ее семантики в польском и чешском языках (§3). На этом вступительном этапе описание не претендует на охват всех тонкостей, связанных с этой конструкцией. Мы здесь не будем проводить разграничения функций внутри результатива. В частности, мы не будем останавливаться на возможной интерпретации интересующей нас конструкции как экспериенциального перфекта; такой интерпретации легко поддается целый ряд примеров (см. примеры 76 и 79). Данная статья нацелена на то, чтобы

\footnotetext{
${ }^{2}$ См. Недялков/Яхонтов 1983, а вслед за ними на материале славянских и балтийских языков (Wiemer/Giger 2005).
}

Славистика XXII/1 (2018) 
начать изучение этой конструкции как таковой. При этом мы будем опираться на пробное корпусное исследование. Однако уже такой первый опыт позволил определить различия в употреблении изучаемой конструкции в польском и чешском языках, которые «невооруженным глазом» вряд ли удалось бы вскрыть и которые играют роль для определения значения предложного результатива (см. §4).

\section{2. О состоянии исследований}

В данном разделе мы проведем краткий обзор сначала по неславянским языкам (§2.1), потом по славянским языкам (\$2.2). Как оказалось, сведения одинаково скудны и поверхностны, а отчасти даже недостоверны.

\section{1. Возможные кандидаты предложного результатива в неславян- ских языках}

Наверное, наиболее известный эквивалент выделяемой нами западнославянской конструкции наблюдался в ирландском английском (4), а также - в самом ирландском языке (5). Применительно к обоим языкам эта конструкция подводилась под понятие перфекта.

(4) She's after selling the boat.

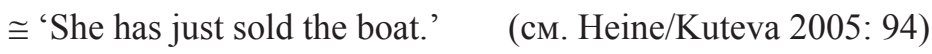

Tá $\quad$ Siobhán tar éis litir a scríobh.
быть.PRS Шивон после письмо РTC писать.VN
'Шивон только что отправила письмо.'
мер и его перевод приводятся за Байда 2016: 170)

Появление этой конструкции в ирландском английском объясняют влиянием ирландского (или вообще кельтского) субстрата. В ирландском языке (и ряде других кельтских языков) такая конструкция довольно продуктивна, хотя и достаточно редка на уровне текста (см. Байда 2016 для обзора и подсчетов). Продуктивность в ирландском языке отражается в возможности образования от практически любого глагола (включая связку), а также прогрессива и пассива (в образовании которых участвует связка). Для сравнения с этим: в западнославянских языках данная конструкция только весьма редко осуществляется с настоящими nomina actionis (см. §4.3).

Далее в Tommola (2000: 474-475) дается ссылка на французскую конструкцию être après + INF, однако с указанием на то, что этот оборот используется как перифраза прогрессива (напр., Il est après lire. 'He is reading.'). ${ }^{3}$ Его возникновение, скорее всего, следует объяснить на основе более старого зна-

${ }^{3}$ П.М. Бертинетто отмечает ее распространение также на севере Италии: “(...) mainly used in the Loire Valley and in parts of the Southof France. A limited geographical distribution has also to be ascribed to the morphologically almost equivalent Italian marginal type [essere dietro a INF], which can be found only in some areas of the North-East." (Bertinetto 2000: 594) 
чения предлога après 'во время, вслед за' или '(находиться) за чем-либо’; тогда и становится вполне понятным использование инфинитива (вместо отглагольного существительного).

\section{2. Об исследованиях по славянским языкам}

В работах по славянским языкам изучаемая нами конструкция привлекала внимание в лучшем случае попутно; за редкими исключениями ее не учитывали даже работы, посвященные предложным конструкциям, с одной стороны, и обзоры по предикативным схемам, с другой. По нашим данным, первыми исследователями, обратившими внимание на интересующую нас предикативную конструкцию, были Д. Вайс (Weiss 1977: 104), Х. Томмола (Tommola 2000: 474-475) и М. Гигер (Giger 2003: 24). При этом они о ней упоминали в связи с результативными конструкциями и именно для польского или чешского языка. Кроме них, удалось нам «выловить» всего лишь горстку замечаний, которые мы здесь представим по отдельным языкам. Мы не претендуем на полноту охвата, хотя мы проверили все авторитетные грамматики западнославянских языков и впрочем считаем, что найденные сведения (а также их отсутствие) достаточно показательны для общего положения дел. ${ }^{5}$

\subsection{1. Западнославянские языки}

2.2.1.1. Для чешского языка об изучаемой конструкции первый упоминает Шмилауэр (Šmilauer 1947: 154) в разделе о связке, точнее: среди других примеров комбинации связки с предложными оборотами. Он приводит всего лишь один личный пример:

$$
\text { Naši myslivci byli již po snídani. (Vančura) }
$$

'Наши охотники уже позавтракали [были принявши завтрак].'

Второй раз конструкция упоминается в Trávníček (1951: 1284) в контексте обсуждения предлога ро. Он подает больше примеров, также безличные:

\footnotetext{
${ }^{4}$ На эту мысль навел нас Владимир Плунгян, которому за это приносим свою благодарность. По свидетельству этимологических словарей, франц. après изначально употреблялось с пространственным значением '(находиться) за чем-либо', но потом распространилось и стало доминантным как временной предлог со значением 'после' (Dauzet 1938: 43; Block/ von Wartburg 19685: 32). Не исключено однако, что в определенных контекстах сохранялось его старофранцузское пространственное значение 'близко (к)' (см. Gamillschegg 1969²: 45), тем более что современный словарь (Robert $1985^{2}: 492$ ) подает употребления типа être, rester, demeurer ... après qqch. = 's'en occuper activement, y travailler actuellement', которое выражает смысл прогрессива. Не исключено, что après расширил сочетаемость на инфинитив, исходя из этого употребления. Конечно, вопрос требует систематического изучения.

5 За помощь в наших поисках мы хотим поблагодарить в первую очередь Людмилу Попович, которая посылала нам полезные сведения по украинскому, сербскому и словенскому языкам (§2.2.2), а также Мацея Гроховского за ссылки на ряд работ, посвященных польскому языку (§2.2.1.4). За сведения по верхнелужицкому языку мы признательны Кате Бранкачк и Ленке Шольце (Šołcić).
} 
(7) je, máme po práci; ${ }^{6}$ je po koncertě, po divadle; je po všem [= po skončení všeho, konec všeho]; je po naději [= naděje se skončila, ukázala se lichá] 'работа у нас закончена; концерт, театр закончился; все позади [= по окончании всего, конец всего]; надежда пропала [= надежда закончилась, оказалась напрасной]'.

Более подробно конструкция обсуждается в Petr et al. 1987 в разделе по структурным схемам с подлежащим (,Vzorce se subjektem“). Там сказано следующее:

\subsubsection{2 $\mathrm{S}_{\mathrm{n}}-$ Vf být - ADVLoc / ADVTemp}

[1] Včera byl vitr, ale mlha byla též. Bude velké sucho. [2] Z věže je krásný rozhled. Byl hluk, a tak jsem nic neslyšel. [3] Byl začátek ledna. Včera byl Svátek práce. Před týdnem bylo 6. prosince, Mikuláśe. Byla středa. [4] Bylo po žních. Je po všem. Už bylo pozdè na návrat.

Predikát se shoduje se subjektem, je-li jím nominativ, jinak má tvar 3. sg. neutra. Pozici $\mathbf{S}_{\mathrm{n}}$ zaujímají subst. pojmenovávající zejména atmosférické jevy (i), smyslové vjemy (ii) a časové údaje, bud' př́imým označením časového bodu (iii), nebo vztažením k němu (iv). (...)

(Petr et al. 1987: 215; выделено нами, ТБ/БВ)

Эту справку можно прокомментировать следующим образом:

Сочетания být po+NOUN ${ }_{\text {Lос }}$ рассматриваются только как частный случай осуществления схем простых предложений, в которых после být следует „адвербиальное определение“, причем в одном ряду приводятся примеры, в которых предложный оборот ро+ $\mathrm{NOUN}_{\text {ьос }}$ имеет статус либо сказуемого, либо обстоятельства.

Следовательно, предикативное употребление как таковое не выделяется.

Выделенная полужирным формулировка очевидным образом некорректна. Bo фразу být po+ NOUN ${ }_{\text {ьос }}$ не всегда входит именная группа в именит. падеже $\left(\mathrm{S}_{\mathrm{n}}\right)$ : под [4] подобных примеров не приводится, а именно только эта конструкция для нас релевантна.

Очевидно, что мнимый единый образец на самом деле объединяет две разные конструкции: все приведенные примеры описывают состояния, но только под [4] они могут характеризоваться результативными (о различиях между стативом и результативом см. Недялков/Яхонтов (1983: 7-8) и Wiemer/Giger (2005: 1-2).

B Grepl/Karlík (1998: 84) пример Bylo po žních (prázdninách) приводится в той же связи, т.е. среди типов предикации, которые указывают на вре́менные состо-

\footnotetext{
${ }^{6} \mathrm{~B}$ отличие от польского языка $р о+\mathrm{NOUN}_{\text {Lос }}$ создает конструкцию также с mít 'иметь' (похоже в словацком с $m a t^{\prime}$ ), но она реже, чем с $b^{\text {Ĺt }}$. Не вникая в подробности, можно сказать, что корпусный запрос на $b y ́ t+p o+$ LOC выдает приблизительно пять раз больше примеров, чем запрос на mit + po + LOC. Когда обе конструкции возможны с одинаковыми лексемами (напр. mit po škole и být po škole), конструкция с být более частотна, а лексический диапазон конструкции с mít более ограничен уже потому, что нет безличного варианта.
} 
яния ('někdy je nějaký čas'). То есть, снова результатив и статив не различаются. Но интересно, что, так же как в Petr et al. (1987), внимания были удостоены только предложения, которые соответствуют выделенному нами выше безличному типу. Грепль и Карлик (там же) приводят также синтаксически однотипный пример с предлогом pred: Je před maturitami $\approx$ 'Он/Она собирается сдавать экзамен зрелости’. Можно подумать, что авторы оба предлога в составе безличных предикаций трактуют наравне. Действительно, предшествование и следование друг к другу находятся в отношениях конверсивности и можно рассуждать, являются ли временные отношения, задаваемые предлогами ро 'после' и przed/před 'до, перед’, зеркальными отражениями друг к другу. К этому вопросу мы вернемся в $§ 3.3$.

2.2.1.2. В литературе по словацкому языку нам удалось найти одно единственное упоминание об интересующей нас конструкции. В Синтаксисе Орловского (Orlovský 1971³: 330) как бы между прочим, в разделе по предлогам, приводится пример:

$$
\text { Bolo po tanečnej zábave. (Jesenský) }
$$

'Танцы закончились.'

Этот пример тоже соответствует безличному варианту предложного результатива. В словацком национальном корпусе наугад удалось найти также примеры личного варианта; см. (9-11):

(9) Vtedy som bol po operácii, zápas som sledoval z tribúny.

'Тогда мне только что сделали операцию, за матчем я следил с трибуны.' (prim-8.0; SME2009/02)

(10) Mary už bola po smrti, ked' som dorazil. Filip chcel zomriet'.

'Мэри уже умерла, когда я приехал. Филип хотел умереть.'

(prim-8.0; Katarína Soyka - Lokaj)

(11) Už bolo po omši, l'udia opustili kostol.

'Служба уже закончилась [досл. было после службы], люди вышли из костела.'

(prim-8.0; SME2017/06)

2.2.1.3. Исследователи польского языка обращали внимание на предложный оборот $р о+\mathrm{NOUN}_{\text {เос }}$ почти только в его употреблении в качестве обстоятельства (напр. Po obiedzie wrócit do pracy 'После обеда он вернулся на работу'; Po jajku dostał wysypki 'Когда он съел яйцо, у него появилась сыпь') или в связи с глагольным управлением (напр. odziedziczyć majątek po rodzicach 'унаследовать достояние от родителей'; spodziewać się poтоcy po przyjacielu 'рассчитывать на помощь 
от друга'). ${ }^{7}$ Исключение составляют работы А.М. Левицкого, Р. Пшыбыльской и Д. Салиньской; в этих работах предикативное употребление предложного оборота четко отделяется от его использования в качестве обстоятельства.

Работа Левицкого (Lewicki 1973) посвящена синтаксическому и семантическому анализу предложных групп, выполняющих функцию именных предикатов. При этом он рассматривает только личные конструкции, а предложной группе $p o+\mathrm{NOUN}_{\text {เос }}$ он в целом уделяет мало внимания. Автор упоминает о ней дважды: один раз при обсуждении случаев, когда предложный оборот заполняют «конкретные существительные». Сюда автор относит и личные имена, и названия субстанций, а примеры, которые представляют личный тип предложного результатива (cp. Mężczyzna byt po wódce 'Мужчина выпил водки [был после водки]'), он ставит в один ряд с примерами совсем другой семантики, именно: с «наследственным» значением (ср. Chłopiec byt po Jerzym 'Мальчик был Юриным сыном') (Lewicki 1973: 144). Это разграничение мы обсуждаем в 4 4.1. Второй раз интересующая нас конструкция затрагивается в контексте случаев, когда место после предлога занимают событийные имена (1973: 200-202). Здесь образец NOUN ${ }_{\text {мом }}+b y c ́$ + po + NOUN $_{\text {Lос }}$ рассматривается как разновидность предикативных схем, означающих, что прекратилась ситуация, в которой подлежащее $\left(=\mathrm{NOUN}_{\text {мом }}\right)$ занимался «действием», называемым предложным оборотом, и больше в этом «действии» не пребывает. ${ }^{8}$ Хотя в этом описании не охватывается ряд моментов предложного результатива, оно содержит элементы, которые используем и мы (см. §3.1), и все приведенные здесь Левицким примеры подходят под наше понимание предложного результатива.

Пшыбыльска (Przybylska 2002: 475-476) выделяет интересующую нас конструкцию $о$ o $+\mathrm{NOUN}_{\text {Lос }}$ как подтип временно́го употребления этого предлога ('после, спустя'). Она подразделяет предикативное употребление предложной группы на два типа, в соответствии с указанными нами выше синтаксическими вариантами (личным и безличным). Семантическое описание проведено в терминах когнитивной лингвистики (в духе Р. Лангаккера), но по сути оно во многом сходится с толкованиями, которые мы предлагаем в $\S \S 3.1-3.2$.

Салиньска (Salińska 2003) анализирует фразы типа i ро NOUN $_{\text {เос }}$ в функции, ограничивающей сегменты дискурса. Таким образом, она охватила часть тех употреблений интересующего нас предикативного предложного оборота, которые подпадают под безличный тип. При этом она указывает на некоторую их продуктивность (ряд существительных, способных занимать позицию $\mathrm{NOUN}_{\text {Lос }}$, в принципе может пополняться). Кроме того она подчер-

\footnotetext{
${ }^{7}$ Cм. Przybylska 1985. В монографии Косек (Kosek 1999) это употребление практически вынесено в заглавие и не упоминается о ро $+\mathrm{NOUN}_{\text {Lос }}$ в качестве самостоятельного сказуемого. Не упоминается о нем также в статьях Клебановской (Klebanowska 1982) и Гроховского (Grochowski 1998); в них обсуждаются вопросы причинно-следственных связей и синтаксической конденсации, в частности вопрос, можно ли признать оборот ро + NOUN в простом предложении эквивалентом союзам типа gdy и kiedy, вводящим временно́е придаточное предложение.

${ }^{8}$ Оборот обозначает „ogarnięcie podmiotu przez czynność z odcieniem nieaktualności tej relacji w momencie czasowym oznaczonym przez czas gramatyczny $V^{\text {być }}$ (Lewicki 1973: 200).
} 
кивает, что предложная группа часто не может употребляться как обстоятельство (12) или, если может, то смысл другой, чем у «омонимичного» обстоятельства (13):

(12a) Poszedtem do niego i po strachu.

'Я пошел к нему и все было позади.'

(12b) *Poszedtem do niego po strachu. (досл.) *‘Я пошел к нему после страха.'

(13a) Skończysz pisać i po balu.

'Кончишь писать, и все дела.'

(13b) Skończysz pisać po balu.

'Кончишь писать после бала.'

Формат ее толкований следует образцам А. Вежбицкой. К анализу Салиньской мы вернемся в 3.2 .1$.

2.2.1.4. Применительно к верхнелужицкому языку о конструкции упоминает справочник (Faska 2009: 200), где в связи со сложными сказуемыми приводятся два примера, один личный (14), другой безличный (15). Безличный пример был приведен уже во введении; аналогичный ему пример (16) взят из корпуса:

(14) Susodźicy su hižo po wobjedźe. 'Соседи уже отобедали.'

(15) Bórze budźe po straše.

'Скоро испуг пройдет.'

(16) Whosćencu sej potom zasy wotpočnje, hdyž budźe po straše.

'Он потом отдохнет в трактире, когда страх пройдет.'

(Hotko; Katholski posot, 1912)

В корпусе (ср. ссылки в конце статьи) удалось найти намного больше вхождений личного, чем безличного типа (напр. на запросы ро wobédźe 'после обеда' и ро snédani 'после завтрака'). Ряд информантов, которые родом из разных частей верхнелужицкого ареала, утверждали, что личный вариант они используют сами, тогда как безличный вариант кажется им странным или устаревшим. Эти утверждения согласуются с фактом, что в корпусе большинство вхождений безличного типа относится к более старым текстам (см. пример 16). Дают ли эти сведения основание для предположения, что безличный тип уходит (или уже ушел) из активного употребления, может показать только систематическое исследование.

\subsection{2. Остальные славянские языки}

Мы продолжим восточнославянскими языками. В академических грамматиках русского языка исследуемый нами предложный оборот в предикативном 
употреблении не упоминается вовсе. Это стоит отметить особенно потому, что эти грамматики в частях, посвященных синтаксису, отводят много места систематическому обзору разных неглагольных типов сказуемых, в том числе таких, которые образуются предложными оборотами. В их перечне предлог после отсутствует. То же самое можно сказать о синтаксическом словаре Г.А. Золотовой (Золотова 1988).

Как оказывается, найти подходящие примеры с после не составляет особого труда, если обратиться к корпусу и прочим источникам в интернете. В определенных текстовых жанрах (напр. в объявлениях и в рекламе) предложные результативы встречаются; ср. ${ }^{9}$

(17) Купить недвижимость в Барселоне: Квартира после ремонта возле Саграды Фамилии. Стоимость: $289000 €$

(www.damlex-realty.ru/property-for-sale/barcelona/...)

(18) Я никогда не видела близко пьющих мужиков, если не считать бомжей, но тут мне сразу пришло в голову: наверное, он после запоя. Небритый человек ...

(Н. Веселовская: Держитесь, девушки!, сборник)

(19) Если это она после похудения, представляю какой там был кабан до похудения! (http://podrobnosti.ua/)

Можно возразить, что такие примеры представляют собой неполные предложения, типичные для рекламы и газетных заголовок. Однако такая интерпретация спорна, а примеры (18-19) нельзя понимать как неполные. Независимо от этого, и прежде всего, все найденные примеры представляют только личный вариант. На его существование обратил внимание Байда (2016: 175-176), который нам также любезно предоставил целый ряд примеров из НКРЯ, среди них следующие:

(20) Мне нездоровилось, я была после простуды.

(21) И я его понимал: он был после инфаркта.

(22) А ведь Ленинград был после блокады.

(23) Далее, если он только что после учебы, я прикрепляю его к опытному мастеру.

(24) Я только что после спектакля. Состояние возбужденное.

По личному сообщению В.В. Байды, в НКРЯ следующие именные группы встречаются в предикативном предложном обороте после $+\mathrm{NOUN}_{\mathrm{GFN}}$ :

(25) инфаркт (3 раза), болезнь (2 раза), операция (2 раза), простуда, тяжелейший инфаркт, перенесенный сыпной тиф, наркоз, роды, аборт, декрет, контузия, ранения, фронт, блокада, «вчерашнее» пиво, тяжелое похмелье, школа, учеба, спектакль, реставрачия.

\footnotetext{
9 За «букет» примеров мы благодарим Наталью Левшину.
} 
Хотя этот перечень не был получен в результате случайной или сплошной выборки, заслуживает внимания, что большинство существительных обозначают болезни или события, связанные со здоровьем; довольно привычны также выражения, относящиеся к образованию (школа, учебы) или к комплексным событиям, связанным с состоянием жилых помещений (ремонт и т.п.). Но в общем и целом, по сравнению с польским и чешским языками лексический диапазон этой конструкции в русском языке очень узок, так что об особой ее продуктивности говорить не приходится.

Еще интереснее ситуация в украинском языке. ${ }^{10}$ И здесь предложный результатив остался «за бортом» внимания как в грамматиках, так и в более специальных работах, посвященных синтаксису, предложным оборотам или семантике предложения. В корпусе примеров мало (см. ниже), хотя «на чутье» в разговорной речи конструкция вполне употребительна. Также словари, как правило, не дают подходящих примеров. Исключением является шеститомный украинско-русский словарь, изданный в 1953-1963 гг. В нем (Кириченко $1961)$ под заглавным словом по приводится ряд фразеологических примеров (в том числе из художествненной прозы), удовлетворяющих критериям обсуждаемого предожного результатива; см., например, коли вже буде по всьому (разг.) 'когда всё будет кончено, когда всё кончится', могло бути по нас (разг.) 'пропали б мы, был бы нам конец' (мы признательны X. Томмоле за то, что указал нам этот источник).

Такого рода случайные сведения и предварительные корпусные данные свидетельствуют о том, что личный тип предложного результатива осуществляется только с помощью предлога після (+ GEN) 'после', а безличный тип - с помощью синонимичного предлога по (+ LOC). Эти наблюдения приводят на мысль, что оба типа находятся в дополнительном распределении по синтаксически разным моделям, причем личный тип осуществляется по «русской модели», в то время как безличный тип соответствует «польско-чешской модели». Более того, безличная конструкция обычно ассоциируется с тем, что «говорящий не одобряет прекращение ситуации» (Л. Попович); см. например

$$
\begin{aligned}
& \text { Напився, та й по роботі. } \\
& \text { 'Напился, и конец работе.' } \\
& \text { Знайшов іншу, та й по любові. } \\
& \text { 'Нашел другую, и конец любви.' }
\end{aligned}
$$

Подобную коннотацию можно приписать также безличному типу в польском языке при определенном лексическом заполнении (см. §3.2). Такое употребление кажется особенно заметным в разговорном языке Львовской области, т.е. в Западной Украине, неподалеку от Польши. Касается это также примеров, в которых валентность предлога по занимает предметное существительное, напр. Вже по тарілці 'Тарелка разбилась' (досл. 'уже после тарелки', т.е. она пропала). В таком случае результативное состояние относится к тому, что этого пред-

\footnotetext{
${ }^{10}$ Всеми сведениями и ссылками по украинскому (а также по словенскому) языку мы обязаны Людмиле Попович.
}

Славистика XXII/1 (2018) 
мета больше нет (см. §3.2.2). Однако в корпусе встречаются практически только примеры с универсальным кванторным все, напр.

I відразу ж було повідомлено, що це самогубство, та й по всьому.

'И сразу же было сообщено, что это самоубийство, вот и все дела.'

(КУМ, Ліна Костенко)

Такие употребления кажутся устойчивыми оборотами (вместе с коннективом $m a \check{u}$ ), т.е. результатами лексикализации. Такая оценка справедлива также по отношению к примерам с указательными местоимениями, причем с ними функция всего оборота от собственно временно́й семантики отдаляется еще заметнее, чем в случае с кванторным словом; ср. например:

\section{Метелясться щзось, та й по тому. (КУМ, Марина Соколян) 'Болтается что-то, только и всего.'}

В том и в другом случае оборот имеет скорее всего функцию замыкания фрагмента текста, когда подводятся итоги под сказанное (см. подобную функцию в польском, §3.2.1).

Личный вариант конструкции, в свою очередь, обычно встречается в заглавиях и в рекламе, так же как и ее русское соответствие (см. выше):

$$
\begin{array}{ll}
\text { Квартира після ремонту. } & \text { 'Квартира после ремонта.' } \\
\text { Тіло після схуднення. } & \text { 'Тело после похудения.' }
\end{array}
$$

Перейдем теперь к южнославянским языкам. О них сказать почти нечего. У нас вообще нет сведений о болгарском и македонском языках. Относительно хорватского языка можно упомянуть только следующий пример, который приводится в Байда (2016: 176):

Upravo sam bio poslije kupanja, kad su stigli gosti.

'Я только что искупался, когда пришли гости', букв. 'я был после купания'.

По единогласному суждению информантов подобная конструкция неупотребительна, то же самое верно относительно сербского: говорящего бы поняли, но вряд ли кто-либо так сказал бы спонтанно. ${ }^{11}$

Что касается словенского языка, то в грамматике Топоришича (Toporišić 1976: 336) личный тип интересующей нас конструкции мимоходом упоминается в контексте плюсквамперфекта. Топоришич приводит предикативное употребление po večerji 'после ужина' как функциональный эквивалент глагольных предикатов в функции предшествования:

\footnotetext{
${ }^{11}$ Информанты хорватского: Т. Гнятович, Р. Матасович, А. Пети-Стантич; информанты сербского были опрошены Л. Попович.
} 
(32) Ko se je Janez zvečer vrnil domov, so bili že večerjali / so bili že odvečerjali / so bili že po večerji.

'Когда Янез вечером вернулся домой, уже ужинали / поужинали [досл. уже были ужинали / были поужинали] /уже были после ужина.'

\section{3. Опыт толкования}

В этом разделе мы даем первую попытку охватить значение предложного результатива, причем нам важно показать, что личный и безличный типы отличаются друг от друга не только синтаксически (наличием vs. отсутствием подлежащего), но также семантически. Мы вполне допускаем, что предложенные ниже толкования можно будет усовершенствовать, в частности, что к каждому толкованию можно будет пристроить более точные характеристики. Однако мы также предполагаем, что толкования с дополнительными характеристиками окажутся иерархически подчиненными тем, которые мы здесь представим. Иначе говоря: мы довольно уверены, что наши толкования создают верхние узлы таксономии и что их уточнения займут более низкие позиции в таксономической иерархии, охватывая варианты с более ограниченным кругом лексического заполнения предиката, т.е. позиции именной группы, управляемой предлогом. Однако все варианты объединяются функцией указания на результативное состояние, т.е. на состояние $\mathrm{C}_{2}$, возникшее вследствие того или иного события, разделяющего некое предыдущее состояние $\mathrm{C}_{1}$ от актуального состояния $\mathrm{C}_{2}$.

Еще одно общее свойство предложного результатива, независимо от синтаксического типа и лексического заполнения, заключается в том, что он плохо сочетается с отрицанием. Во всем нашем польском материале (см. $\S 4)$, а также в обсужденной в 2 литературе, нам не попался ни один пример с отрицанием; в чешском материале такие примеры засвидетельствованы (см. ниже). Редкость таких примеров вряд ли случайно. Она вытекает из коммуникативной функции предложного результатива: об определенном подлежащем (в личном типе) или ситуации в целом (в безличном типе) утверждается некое состояние; о нем стоит сказать, потому что это состояние является следствием чего-то, что случилось (если предложный оборот содержит событийное имя) или что случилось с предметом / лицом, связанным с определенным событием (если предложный оборот содержит предметное / личное имя или местоимение). Отрицание означало бы сообщение о том, что не случилось ничего, а это было бы лишено прагматической мотивации. Вообразимо употребление при контрастивном выделении; см. придуманные польские примеры:

(33a) Oni nie sa po ślubie, tylko po słowie / zaręczynach.

$\approx$ 'Они еще не поженились [после женитьбы], а только после помолвки.'

(33b) Jeszcze nie byto po operacji, dopiero po wizycie u lekarza.

z 'Операцию еще не провели, а только сходили к врачу.'

Славистика XXII/1 (2018) 
Без такого контраста отрицание звучит странно, если это не реакция на утверждение собеседника:

(34) A: Jacek i Małgosia sa po ślubie / się pobrali.

B: Nieprawda. Jacek i Małgosia nie sa po ślubie.

$\approx$ 'А: Яцек и Малгося поженились.

B: Неправда. Яцек и Малгося не поженились.'

Ожидается продолжение, которое вводило бы поправку к утверждению собеседника. Обнаруженные нами чешские примеры именно этого типа; ср.

Nejsem po úraze - mám pouze problémy s páteři a kloby [sic!].

'У меня не было аварии - просто у меня проблемы с позвоночником и суставами.'

(ABM; brc.cz)

\section{1. Личный тип}

Свое толкование личного варианта мы опережаем стереотипными примерами:

(36a) польский Oni sa po piwie / po kursie / po egzaminie / po ślubie.

'Они выпили пиво / окончили курс / сда(ва)ли экзамен / поженились.'

Samochód byt po naprawie. / Dom jest po pożarze.

'Машина была починена. / Дом сгорел (пострадал от пожара).'

(36b) чешский Jsou po večeři / po operaci / po promoci.

'Они (по)ужинали / прошли операцию / после торже-

ственного

вруения диплома.'

Byty jsou po rekonstrukci. / Dim je po povodni.

'Квартиры после ремонта. / Дом залило (пострадал от наводнения).’

\section{Толкование}

(37) '(i) До промежутка времени $\mathrm{t}_{0}$, на который ссылает время связки (být / być), peферент R, занимающий место подлежащего, испытывал контакт (опыт) с событием $\mathrm{E}$, обстоятельствами С или с объектом Оb, который является составной частью Е или С. Существительное в предложном обороте ( вает $\mathrm{E}, \mathrm{C}$ или $\mathrm{Ob}$, а состояние референта $\mathrm{R}$ в промежутке $\mathrm{t}_{0}$ является следствием этого контакта. Начало $\mathrm{t}_{0}$ непосредственно примыкает к событию Е, связанному с С или $\mathrm{Ob}$. 
(ii) Это состояние прямым образом не называется, а участникам речевого акта самим приходится устанавливать причинно-следственную связь между Е, $\mathrm{C}$ или $\mathrm{Ob}$ и состоянием $\mathrm{R}$.

[(iii) Причинно-следственная связь между E / C / Ob и R обнаруживает различную степень конвенционализации.]'

Компонент (i) описывает временно́е соотношение между сегментом в ассертивной части (состоянием в моменте $\mathrm{t}_{0}$ ) и предшествующим событием или просто предшествующей ситуацией, которая закончилась к промежутку $\mathrm{t}_{0}{ }^{12}$ Начало этого промежутка примыкает к этому событию (или ситуации) непосредственно, ${ }^{13}$ что подкрепляет релевантность этого предшествующего сегмента для актуального состояния в $\mathrm{t}_{0}$. Компонент (ii) указывает на связь между этими двумя сегментами; эта связь обусловлена метонимией, тип и сложность которой бывает разной (см. ниже). В любом случае конкретный характер состояния, которое относится к ассерции, только имплицируется, поскольку выводится оно из общих знаний о мире. В этом заключается примечательное отличие предложного результатива от большинства других известных результативных конструкций: помимо того, что говорящий утверждает что-то о какомто состоянии, возникшем из смены ситуации, состояние это «не называется по имени». Компонент (iii), собственно говоря, не относится к толкованию как таковому, но связан со статусом толкуемой конструкции в языковой системе. Об этом статусе см. в 33.3 и в выводах (см. §5).

Существенно осознавать, что значение конструкции основывается на метонимическом сдвиге, который более опосредован, чем в обычном результативе. Временной сдвиг - от смены ситуации (предельного события) к примыкающему новому состоянию - встроен в определение результативной конструкции как таковой, но в предложном результативе он обусловлен более косвенной связью между предшествующим событием и результирующим состоянием (напр. обед $\supset$ сытость, экзамен $\supset$ диплом, право заниматься определенной профессиональной деятельностью, ремонт $\supset$ годность в качестве жилой площади) или между определенными обстоятельствами и состоянием после их преодоления (напр. тяжелая работа $\supset$ усталость, война / исполнение 50-и лет $\supset$ жизненный опыт). То, что предшествовало этому состоянию, называется словом, которое этимологически никак не связано с выражениями, которые могли бы обозначать это состояние; из этого свойства вытекает имплицитность утверждения о результирующем состоянии, которая включается в компонент (ii) толкования.

Вдобавок к этому качественному отличию от других результативов предложный результатив осложняется еще одним метонимическим шагом, если в пред-

\footnotetext{
${ }^{12}$ Следует еще уточнить, можно ли этот предшествующий сегмент считать пресуппозицией (в логическом смысле). Так следует считать, если можно показать, что этот сегмент не оказывается затронутым сферой действия отрицания. Однако не совсем ясно, как нужно интерпретировать предложения типа пол. Oni nie sa po egzaminie / po kursie / po ślubie: результата нет, но была попытка (или начало действия), т.е. 'Неправда, что они сдали экзамен / закончили курс / заключили брак (и сейчас держат диплом / являются мужем и женой), но они экзамен сдавали / курс посещали / собирались жениться’? Предложенный тест звучит довольно искусственно, поскольку предложный результатив не встречается с отрицанием (см. выше).

${ }^{13}$ На это свойство обратил внимание Байда (2016: 175), назвав его 'иммедиатностью’.
} 
ложном обороте употребляется не событийное, а предметное имя (напр. пол. ро lampce wina досл. 'после бокала вина'). С предметными именами сдвиг бывает более опосредован, чем при обычной метонимии, например типа 'вместилище $>$ субстанция' (выпить стакан сока) или типа 'художник/писатель и т.п. > его творчество' (увлекаться Бетховеном / Пушкиным), или чем в случае pars pro toto (например Билеты будут стоить 5.000 рублей с носа). Опосредованность соотношения состояния, которое утверждается в предложном результативе, и предшествующей ему ситуации можно представить следующим образом:

(а) название объекта (в самом широком смысле) >

(б) событие, связанное с этим объектом >

(в) состояние, следующее из этого события. ${ }^{14}$

Ср. польские примеры из корпуса: ${ }^{15}$

ja wtaśnie jestem po piwie, a co?

'я как раз выпил пива, ну и что?'

(APM; przystanek-julita.blogspot.sk)

(39) Bardzo proszę o radę. Nie śpię kilka miesięcy, jestem po raku tarczycy(,) c73 i jodzie. Nie śpię w ogóle.

'Очень прошу Вас дать совет. Я не сплю уже пару месяцев, у меня был рак щитовидки, меня лечили с73 и йодом.'

(APM; portal.abczdrowie.pl)

Видимо, предметное имя в этой позиции может встретиться только, если подлежащее обозначает человека, а если подлежащее выражает неодушевленный предмет, в предикативном предложном обороте мы можем найти только событийное имя (и метонимический сдвиг упрощается). По крайней мере, нам пока неизвестно ни одного контрпримера. Отметим также сразу, что наиболее сложный тип, в котором метонимический сдвиг начинается с названия объекта (см. (а)), довольно распространен в польском, но нам неизвестны соответствующие примеры для чешского языка (см. §4.3).

Напоследок подчеркнем, что результирующее состояние в (в) относится либо к изменениям в конкретно-физическом мире, либо к миру социальной значимости. «Физическая» vs. «социальная» природа состояния, видимо, зависит от того, выполняет ли позицию подлежащего существительное, называющее предмет (в широком смысле, например машина, квартира) или человека (или другое живое существо). ${ }^{16}$ Для безличного типа такое обобщение сделать нель-

\footnotetext{
14 По сложности такую цепочку можно сравнить с более известной метонимической цепочкой типа 'автор > произведение > физический объект, представляющий это произведение (экземпляр тиража)'; ср., например, Пушкин стоит на второй полке сверху.

${ }^{15}$ Условные сокращения корпусов см. в конце статьи (в библиографии) и во введении к 4.

${ }^{16}$ По-видимому, единственным исключением здесь является чеш. Xje po smrti 'X умер, не жив' (досл. 'Х после смерти'), для которого нет польского эквивалента.
} 
зя; как мы увидим в §3.2.2, он вполне (и предсказуемым образом) может относиться к физическим изменениям также и человека (людей).

\section{2. Безличный тип}

С безличным типом дела обстоят несколько сложнее. Видимо, за ним скрываются две разные конструкции. Обсудим их обе по очереди.

\subsection{1. Конструкция, ограниченная событийными именами}

Первая безличная конструкция от семантики личной конструкции отличается, по сути дела, только тем, что в ней метонимические сдвиги не осложняются объектными именами; позицию существительного в предложном обороте заполняют только событийные имена (включая их «заместителей», см. ниже). Эту конструкцию можно проиллюстрировать следующими стереотипными примерами:

$$
\begin{aligned}
& \text { польский Już jest po obiedzie. } \\
& \text { 'Обед уже закончен.' } \\
& \text { Wkrótce już byto po deszczu. 'Скоро дождь был позади.' } \\
& \text { Byto po bitwie. } \\
& \text { 'Битва закончилась.' } \\
& \text { чешский Rázem bylo po kšeftu. } \\
& \text { Pak, když poznala, } \\
& \text { 'Вдруг со сделкой было } \\
& \text { покончено.' } \\
& \text { že je po večeři ... } \\
& \text { 'Но когда узнала, что ужин уже был...' }
\end{aligned}
$$

(41) '(i) До промежутка времени $\mathrm{t}_{0}$, на который ссылает время связки (být / być), имело место некое событие Е или обстоятельства С. Существительное в предложном обороте ( $р о$ + LOC), называет либо Е, либо С. Состояние в промежутке $\mathrm{t}_{0}$ является следствием $\mathrm{E}$ или С. Начало $\mathrm{t}_{0}$ непосредственно примыкает к событию Е, связанному с С.

(ii) Это состояние прямым образом не называется, а участникам речевого акта самим приходится устанавливать причинно-следственную связь между E / C и состоянием R.

[(iii) Причинно-следственная связь между E / C и R обнаруживает различную степень конвенционализации.]'

Как видно, толкование безличной конструкции отличается от толкования личной конструкции только в первом компоненте (i) и тем, что в компоненте (ii) отсутствует возможная переменная $\mathrm{Ob}$.

В этой конструкции чрезвычайно часто появляется кванторное выражение 'всё' (см. §4.3), а событие Е или обстоятельства С вводятся лишь на правах смазанной (неточной) отсылки. Эта ссылка раскрывается на основе предыдущего контекста (анафорически) или знаний о ситуации; ср. 


$\begin{array}{lll}\text { (42a) польский } & \text { O drugiej byto po wszystkim. 'В два часа все было позади.' } \\ \text { (42b) чешский } & \text { Brzy bude po všem. }\end{array}$

Но место после предлога могут заполнять также определенные выражения с предельно общим значением, например пол. sprawa 'дело', относящиеся к событиям или фактам. В этот разряд входят существительные, которые употребляются не в прямом значении, а как заместители таких предельно общих выражений. Степень конвенционализации таких заместителей разная, но довольно устойчивыми оказываются пол. klopot, problem, krzyk, ptaki, herbata, чеш. starost, problém, sranda, paráda, ptáci. ${ }^{17} \mathrm{Cp}$. польские примеры (43-44) из работы Салиньской (Salińska 2003) и чешские (45) из корпуса SYN2015:

Teraz to mówisz, jak już po herbacie.

'Ты говоришь это сейчас, когда уже поздно.'

Jak się spóźnimy, będzie po ptakach. 'Если мы опоздаем, все пропадет.' Wskoczyt do wody i po bólu. 'Он вскочил в воду и всё.'

(44) No i po krzyku. (говорит мать ребенку, которому только что сделали укол) 'Ну и всё, потерпел(а) и прошло.'

(45) Ted' bude po starosti, život se strastí zprostí.

'Сейчас забот больше не будет, жизнь освободится от страданий.'

Jenže pak farmu obehnali elektrickým plotem a bylo po srandě.

'Однако ферму огородили электрическим забором и проказам пришел конец.'

(...) a když přišel nečekaný déšt', bylo po parádě.

'.... когда начался нежданный дождь, болыше нечего было веселиться.'

Относительно польского языка Салиньска указывает на то, что такие обороты обычно замыкают высказывание, т.е. определяют границу неких абзацных единиц дискурса. Тогда они могут служить самостоятельными высказываниями, связь которых с предыдущим контекстом, как правило, остается имплицитной. ${ }^{18}$ Автор также настаивает на том, что слово $i$ не является союзом, но входит в состав этого оборота как его неотъемлемая часть. Доказательством служит факт, что $i$ не может быть заменено союзом (cp. (46b)). Тем не менее можно утверждать, что $i$ делает эксплицитной связь с предшествующим дискурсом, указывая на то, что вводимая им фраза комментирует непосредственно предыдущий фрагмент текста. Перед $i$ обычно выступает пауза (см. (46а)):

\footnotetext{
${ }^{17}$ Совершенно окказионально можно встретить примеры, в которых, например, пол. herbata 'чай' (в смысле чаепития) или чеш. ptáci ‘птицы’ употреблены в прямом смысле.

18 „Wyrażenia te mogą funkcjonować jako samodzielne wypowiedzenia lub być dodane do poprzedzającego kontekstu werbalnego, bez nawiązania do jego treści (sytuacja pozajęzykowa, do której odnosi się dana jednostka, nie jest zwerbalizowana).” (Salińska 2003: 271)
} 
(46a) Skończysz to \| i po sprawie. 'Закончишь это \|и всё.'

(46b) *Skończysz to, tudzież po sprawie.

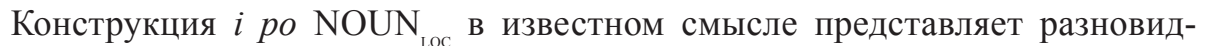
ность предложного результатива, поскольку разделяет с ним ряд нетривиальных свойств.

Салиньска в оборотах типа $i$ po $+\mathrm{NOUN}_{\text {ьос }}$ выделяет различные типы оценочной семантики и в зависимости от «содержания» оценки она проводит подразделение на группы (иногда состоящие из одного представителя). Единственным нейтральным в этом отношении существительным является выражение $i$ po sprawie, а шире всего представлена группа, выражающая облегчение или подобные эмоции: комментируемая прошедшая ситуация оценивается как неприятная, а факт, что она закончилась, вызывает положительные эмоции; сюда относится также $i$ po wszystkim. В иных случаях выражается сожаление, что закончилась приятная ситуация ( $i$ po herbacie; $i$ po ptakach). Тип оценки входит в семантику конструкции $i$ ро + NOUN $_{\text {Lос }}$ в соответствии с существительным, заполняющим валентность предлога ро, а прагматическое свойство этой конструкции, независимо от этого заполнения, одинаковым образом сводится к «текстоограничительной» функции, о которой говорилось выше.

Толкования, предлагаемые Салиньской, следуют «формату» толкований А. Вежбицкой, а в их центре (для каждой отдельной группы) находится тип оценки. Поэтому для нейтральной фразы $i$ po sprawie толкование сводится к следующему: ${ }^{19}$

(47) 1. 'o tym, co się zdarzyło/działo [się zdarzy/będzie dziać] (wiesz, o czym mówię), mówię:

to przestało [przestanie] się dziać'

- в отношении действий, напр. Skończysz / skończyłeś to i (będzie / byto) po sprawie.

2. 'o tym, co powiedziałem, mówię:

to przestało [przestanie] się dziać'

- в отношении речевых актов, напр. (Powiesz mu, że) Nie zrobiteś / zrobisz tego, i jest po sprawie.

Такое толкование само по себе не указывает на результативное состояние; в ассерции находится только то, что «бывшее прошло». Но чаще всего к тому, что «прошло», добавляется оценка, которая описывает внутреннее состояние субъекта речи, а это состояние как раз совпадает со временем, указанным связкой. Получается, что опыт толкования Салиньской косвенно наводит на особый тип

\footnotetext{
${ }^{19}$ Cм. Salińska (2003: 286). Добавления в квадратных скобках, а также пояснения под вариантами толкования наши. Толкование разделено на два варианта, поскольку Салиньска сочла нужным различать комментарии к действиям (фактам и т.д.) в окружающем «физическом» мире и комментарии к речевым действиям, т.е. к пропозициональному содержанию того, что участник коммункации мог (может) выразить словами.
} 
результирующего состояния: внутреннее состояние является результатом того, что закончилась ситуация, которую комментирует толкуемый оборот. Вместе с тем, такой опыт толкования, сосредотачивающий внимание на типе оценки, охватывает лишь особый подтип безличного варианта рассматриваемого нами предикативного предложного оборота. Предложному результативу бывает присущ определенный оттенок «социальной значимости», а эмоциональную оценку можно понимать как одну из разновидностей социально значимых ситуаций. Следует однако иметь в виду, что Салиньска задалась целью представить толкования и дискурсивные свойства оборота с $i$, а не всех типов предикативного употребления предложного оборота с $p o+\mathrm{LOC}$ без подлежащего в польском языке. Вместе с тем, эмоциональная оценка присуща этой конструкции не всегда. Такая оценка иногда просматривается, когда значение существительного в предложном обороте испытывает определенный сдвиг; ср. следующий польский пример, в котором ро тесzи досл. 'после матча', скорее всего, нужно понимать как признание в выигрыше (или проигрыше):

Kapitalny strzat pod poprzeczkę i jest po meczu! Zdruzgotani rywale zaczynaja od środka.

'Мощный удар под перекладину и всё! Сокрушенные соперники начинают с середины поля.'

(APM; wisloksieniawa.bnx.pl)

Вопрос о том, насколько правомерно рассматривать эмоциональную оценку как часть конвенционального значения предикативного оборота $p o+\mathrm{LOC}$ с данной лексемой (mесz), следует дальнейшего разъяснения. Однако трудно усмотреть такую оценку (на правах конвенциолнального элемента) в стереотипных примерах как пол. Byto po obiedzie или соответственно чеш. Bylo po večeři (см. примеры 40a, 40b), когда существительное употребляется в своем первичном (прямом) значении. То же самое верно в отношении личного варианта (см. §3.1) и второй безличной конструкции, к обсуждению которой мы приступаем сейчас.

\subsection{2. «Уничтожительная» безличная конструкция}

Второй вариант безличного типа предложного результатива, скорее всего, нужно признать особым его значением, потому что этому варианту нельзя приписать ни толкование, которое мы предложили в \$3.2.1 для безличного результатива, ни толкование Салиньской (см. 47). Различиям в значении соответствует дополнительное распределение «онтологических» групп существительных, управляемых предлогом. Сравним следующие польские примеры с примерами в 3.2 .1 :

\section{польский}

(49) Naprawa jest konieczna - bo jak przeskocza to będzie po silniku-ale też bardzo droga.

'Починка необходима - ведь если [ремни] соскользнут, то конец мотору - да и стоит очень дорого.'

(APM; botak.jogger.pl) 
(50) (...) na szczęście pitka straciła impet na ręce Włodasa, gdyby nie to, już bytoby po szybie.

'... к счастью, мяч потерял стремительность, когда попал в руки

Влодасу; если бы не это, то оконного стекла уже бы не было.'

(NKJP; kanał książka. Wióry)

(51) Wóz wyjeżdża zza węgła, strzela, i w dwie sekundy i jest po Drabowiczu.

'Автомобиль выруливает из-за угла, стреляет, и за две секунды Драбовича нет.'

(NKJP; kanał książka. Afrykanka)

(52) po co jakies wyszukane przyklady z kosami, kijami (...), wystarczy 2

napastnikow i jest po tobie (...).

'зачем какие-нибудь изысканные примеры с косами, палками (...), достаточно 2 нападающих, и тебя больше нет.'

(NKJP; www.forumowisko.pl, 2006)

\section{чешский}

(53) Umřeme všichni, kdo ví, třeba už zejtra bude po mnĕ!“”

'«Все мы умрем, кто знает, возможно уже завтра меня не станет!»'

(SYN2015; Po Fredrikovi)

(54) Zasažený kovboj tiše klel, svijel se, ale za chvili bylo po něm.

'Ковбой, в которого попала пуля, тихо клялся, вертелся, но через момент его не стало.'

(SYN2015; Nesmrtelný)

(55) Houbičku namočte do čisté vody a udělejte s ní totéż. A je po bakteriich. 'Губку замочите в чистой воде и сделайте с ней то же самое. И уже бактерий нет.'

(ABM; speedexpress.cz)

В §3.2.1 в примерах предложная группа «заполнялась» событийным именем (или его заместителем, относящимся к известному по контексту событию или факту), тогда как в примерах (49-55) существительные в предложной группе обозначают предмет или человека (людей). Сюда можно причислить существительные, обозначающие то или иное учреждение, завод, институт и т.п., а это обозначение по метонимии легко переносится на коллектив людей, связанных с этой институцией; ср. польский пример:

Славистика XXII/1 (2018) 
(56) (...) zdążyli się pokłócić i już było po spótdzielni.

'...успели поссориться, и уже кооператива не было.'

(APM; biznesspoleczny.pl)

Данному варианту можно приписать отдельное значение, потому что люди и предметы, а также то, что с ними соотносится в разных наименованиях на правах метонимии типа 'люди > коллектив / учреждение с определенным предназначением (> здание / помещение, в котором это учреждение находится / в котором работают люди, связанные с этим учреждением)' могут исчезнуть физически. ${ }^{20}$ Это включает либо уничтожение в биологическом или каком-либо социальном или правовом смысле (смерть, провал на экзамене, увольнение, снятие с должности и т.п.), либо радикальное изменение внешнего облика или уничтожение функциональной целостности (напр., порчу электрических приборов или предметов хозяйственной или ремесленной утвари; см. примеры 4950), а иногда также уничтожение абстрактных величин и отношений (напр., развал какой-нибудь валюты, конец дружбы или, наоборот, вражды); ср. польский пример:

Doprecyzujmy: będzie po Euro, jeśli się w ogóle zacznie, bo (...).

'Уточним: с евро дело будет покончено, если вообще начнется, ведь...'

(APM; blog.zW.com.pl)

Напротив, если место после предлога занимают событийные имена, то из конструкции вытекает просто конец действия (см. толкование Салиньской в 47) или смена ситуации (см. наше толкование в 41); ср. все примеры в 3.2 .1 , а также следующий:

natychmiast doskakiwało do niego dwóch, czasami trzech rywali i bylo po akcji. 'сразу к нему прискакивали два, иногда три соперника и все дела.'

(APM; nowytydzien.pl)

Понятие смены ситуации, конечно, включает и исчезновение, уничтожение и т.П., но обсуждаемая здесь конструкция настолько исключительно и специфически связана с уничтожением - т.е. с утверждением, что того человека или объекта, который назван в предложном обороте, больше нет - что это оправдывает выделить ее в особое значение. Так или иначе, из сказанного становится очевидным, что противопоставляемые здесь два значения безличного типа предложного результатива тяготеют к дополнительному распределению, а это обусловлено природой имен, заполняющих валентность в предикативно употребляемом предложном обороте.

\footnotetext{
${ }^{20}$ Cм. (Przybylska 2002: 476). Смысл уничтожения выдвигается на передний план, если существительное в предложном обороте обозначает живое существо.
} 
Попробуем представить толкование «уничтожительного» значения предложного результатива:

(59) '(i) B промежуток времени $\mathrm{t}_{<0}$, предшествующий моменту времени $\mathrm{t}_{0}$, на который ссылает время связки (být / być), существовал предмет $\mathrm{Ob}$ или человек (группа людей) Hum, называемый существительным в предложном обороте $(p o+\mathrm{LOC})$. Между моментом $\mathrm{t}_{<0}$ и моментом $\mathrm{t}_{0}$ произошло некое событие Е. В момент $\mathrm{t}_{0} \mathrm{Ob} / \mathrm{Hum}$ больше не существует (Ob / Hum исчез, уничтожен или подвергся радикальной деформации). Начало $\mathrm{t}_{0}$ непосредственно примыкает к событию Е. (ii) Исчезновение / уничтожение / радикальная деформация Ob / Нum в промежутке $\mathrm{t}_{0}$ является следствием Е, но участникам речевого акта самим приходится устанавливать, в чем состояло Е и какова причинно-следственная связь между Е и исчезновением (уничтожением, радикальной деформацией) Ob / Hum. [(iii) Причинно-следственная связь между исчезновением $\mathrm{Ob} / \mathrm{Hum}$ и Е обнаруживает различную степень- конвенционализации.]'

Попутно уже отметим, что для чешского языка нам не удадось найти примеров с объектным именем (т.е. соответствий примерам как в 49-50); зато очень распространены примеры с названием человека (или других живых существ) или с местоимением; см. примеры (53-55) и §4.3.

\section{2. Соотносительность с другими предложными оборотами?}

Может возникнуть вопрос, нет ли конструкций с pred / przed $+\mathrm{NOUN}_{\mathrm{INs}}$, которые по аналогии с $р о+\mathrm{NOUN}_{\text {Lос }}$ описывают ситуацию с обратным временным соотношением. Такой вопрос кажется закономерным на основании конверсивных отношений:

$$
\text { A po B 'А следует за / наступает после В’ } \cong \text { před / przed A 'В предшествует A'. }
$$

Действительно, в корпусах можно найти единичные примеры, которые на первый взгляд подкрепляют такое рассуждение. Например, в чешском АВМ мы обнаружили два примера типа Objekt je před rekonstrukcí (но ни одного аналогичного в польском АРM: jest/byt przed remontem), а также примеры с существительным пол. matura / чеш. maturita:

(61) Ted' je před maturitou, ještě jí je devatenáct let, je mladá, uvidíme na základě dalšich lékařských vyšetrení.

'Сейчас она собирается сдавать на аттестат зрелости, ей еще 19 лет, она молодая, мы посмотрим на основе дальнейших обследований врачей.' (SYN4; Deníky Bohemia)

(62) Kiedy Karol zaginąt, starsza Wiktoria byla przed matura, a dużo młodszy Antoś chodzit do zerówki. 
'Когда Кароль пропал, старшая сестра Виктория собиралсь сдавать на аттестат зрелости, а намного младший Антось ходил в подготовительный класс детсада.'

(NKJP: Dom między lipą a bilbordem),

По мнению информантов подобные примеры приемлемы, но по сравнению с предикативным оборотом ро + NOUN $_{\text {Lос }}$ они несравнимо реже (напр. с matura / maturita таких примеров вовсе не было в интернетовских корпусах). Применительно к польскому языку Левицки отметил, что оба предложных оборота широко употребляются в качестве обстоятельств (ср. Przed burza byta chwila cicha i ponura 'Перед бурей был момент тихий и понурый'; Jan po studiach pracowat jako nauczyciel 'После университетской учебы Ян работал учителем'), но в качестве предиката предложный оборот przed $+\mathrm{NOUN}_{\mathrm{INS}}$ напрочь отсутствовал. ${ }^{21}$

Такие эмпирические факты заставляют задуматься, действительно ли следование (ро) и предшествование (před / przed) в речевой практике, а также в языковой системе, трактуются как равноправные члены конверсивной пары (как это вытекало бы из логической эквивалентности в (60)). В таком равноправии нужно усомниться, и, по удачной формулировке Левицкого, причиной может быть „,niewielka wartość wyrażenia przed $\mathrm{N}_{\text {III }}^{\mathrm{n}}$ [= przed $\left.+\mathrm{NOUN}_{\mathrm{INS}} ; \mathrm{TB} / \mathrm{BW}\right]$ dla scharakteryzowania podmiotu. Gdy się powie o kimś Jan jest przed obiadem, to właściwie nie powiedziało się nic o podmiocie, bo nie oznacza to nawet tego, że 'Jan jest głodny”" (Lewicki 1973: 202). По-видимому, предикативное употребление przed + NOUN ${ }_{\text {INs }}$ обычно не вызывает причинно-следственных связей. По крайней мере это случается настолько редко, что их нельзя найти даже на большом массиве текста, и нельзя говорить о том, чтобы такие связи становились устойчивыми - в отличие от будто бы конверсивного оборота с ро. Между (хотя бы имплицитным) указанием последствий какого-нибудь события (Jan jest po obiedzie) и указанием того, что такое событие предстоит (Jan jest przed obia$d e m)$, наблюдается асимметрия «в пользу» указания на последствия; вместе с тем, для схемы przed + NOUN ${ }_{\mathrm{INS}}$ какая-либо смысловая связь сверх простой темпоральной возникает в лучшем случае окказионально, на уровне дискурса.

Почему так происходит, без дополнительных (не только лингвистических) исследований сказать трудно. Можно думать, что людям меньше приходится, или хочется, говорить о предстоящем, чем о только что совершившемся (или о последствиях того, что совершилось или совершится). Можно думать, что хотя бы имплицитное указание на последствия того, что случилось или случится, с коммуникативной точки зрения важнее, чем сообщение о предстоящем в ближайший момент. Но подобные рассуждения о разнице по коммуникативной значимости пока что нужно отнести к спекуляциям, а ответы на вопросы, которые они порождают, могут быть даны только в результате тщательных исследований по речевой практике, независимо от формальных средств, служащих для выражения противопоставляемых здесь временных отношений.

\footnotetext{
${ }^{21}$ См. (Lewicki 1973: 202). Левицки опирался на обширную базу данных, собранную из произведений художественной прозы XX века.
} 
Однако асимметрия между ними не сводится только к речевой практике. Об этом говорят следующие факты и рассуждения. Во-первых, как указано выше, с сообщением о предстоящем (или намереваемом), как правило, не связано никаких причинно-следственных или подобных импликаций, в то время как предикативный оборот ро $+\mathrm{NOUN}_{\text {เос }}$ такие импликации включает на уровне семантических, т.е. устойчивых компонентов. Весь смысл толкований, данных в §3, сводится именно к выявлению тесной связи между темпоральной и причинноследственной связями; причинно-следственная связь остается имплицитной в том смысле, что «содержание» результирующего состояния «домысливается», иногда на основании сложных метонимических переносов, но от этого доопределения нельзя уйти при понимании предложного результатива. То есть, этот компонент включен в конвенциональное значение конструкции. Во-вторых, такую несколько нестандартную результативную семантику оборот $р о+\mathrm{NOUN}_{\text {Lос }}$ приобретает именно в предикативном употреблении: как мы видели в 3.2 .1$, po + NOUN $_{\text {เос }}$ в атрибутивном употреблении часто имеет другое значение или не может реализоваться вообще. Следовательно, результативность является свойством конструкции и ее синтаксического (т.е. сказуемостного) статуса в целом. Практически ничего подобного в случае před / przed + NOUN ${ }_{\mathrm{INS}}$ мы не наблюдаем.

В подспорье этим двум аргументам идут факты, связанные с распределением сопоставляемых конструкций. А именно, в-третьих, все примеры с pred / przed, приведенные в литературе, а также найденные нами в корпусах, иллюстрируют личную конструкцию; нет убедительных примеров без подлежащего, описывающих более, чем временной порядок. Это вряд ли случайно. Ведь как нужно представить себе конверсивный эквивалент, например, к пол. Było po ciązy досл. 'Было после беременности' (т.е. женщина находилась в положении кормящей матери / семейная ситуация сосредоточивалась на младенце)? Изречения типа Było przed ciąża не засвидетельствованы. К каким ситуациям бы они подошли? Чисто конверсивному отношению как раз мешает то, что предложному результативу (как любому результативу) свойственен не только временной порядок (между событием, вызывающим новое состояние, и этим же состоянием), но и причинно-следственная связь, а эта связь нуждается в определенной коммуникативной мотивации. Такая мотивация действительно возникает, если то или иное событие социально значимо (и когда говорящий достаточно уверен, что это событие наступит, или знает, что оно наступило). Это объясняет появление единичных примеров типа чеш. Byl jsem pred maturitou ' $Я$ собирался сдавать на аттестат зрелости' или Di̊m byl před rekonstrukci ₹ 'Дом был в доремонтном состоянии', а также отсутствие примеров типа чеш. ?Byl pred nehodou (досл. 'Он был перед аварией') - при обычном Byl po nehodě ₹ 'Он прошел аварию'. Отметим, что все эти примеры представляют личный тип. Подобная мотивация обнаруживается также в тех единичных примерах, когда пол. przed используется в имплицитной или явной оппозиции к ро, как в примере (74). См. также аналогичное противопоставление (nосле vs. $\partial o$ ) в русском примере (19).

Наконец, и в-четвертых, абсолютно бессмысленно представлять себе конверсив к «уничтожительному» значению безличного типа предложного резуль-

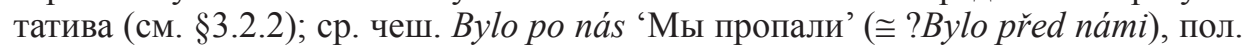

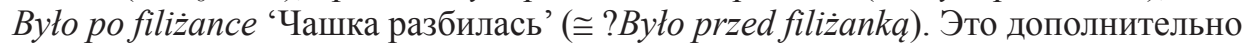


доказывает, что в языке (понимаемом как система оппозиций) ро $+\mathrm{NOUN}_{\text {Lос }}$ и pred / przed + NOUN ${ }_{\mathrm{INS}}$ не трактуются как (конверсивные) аналоги, причем, повторим, именно в предикативном употреблении.

\section{4. Польские и чешские конструкции: сходства и различия}

Приступим сейчас к нашему пробному эмпирическому исследованию. Мы обратились к общедоступным электронным корпусам современных чешского и польского языков: из чешского национального корпуса (С̌ NK) мы использовали самую новую версию (SYN2015), польский национальный корпус (NKJP) мы исследовали с помощью поисковой системы Pelcra, а для обоих языков мы привлекли эквивалентные интернетовские корпуса из собрания Araneum (сост. Вл. Бенко), Araneum Bohemicum Minus (ABM) и Araneum Polonicum Minus (APM). Если для иллюстративных целей мы привлекали данные из других корпусов, мы это особо отметим. Ссылки и сокращения можно найти при библиографии в конце статьи.

Мы сначала объясним процедуру установления списков подходящих вхождений (§4.1), потом сообщим наиболее очевидные результаты (\$4.2) и ряд наблюдений, требующих более детального рассмотрения материала (§4.3).

\section{1. О процедуре анализа}

Мы подвергли анализу чешские и польские предикативные обороты типа být / być $+p o+\mathrm{NOUN}_{\text {Lос }}$ в предикативном употреблении, собранные с помощью сплошной выборки из только что упомянутых электронных корпусов. Выборки были получены на запрос být / być + po + LOC, причем именно только в этой последовательности. Можно полагать, что запрос в этой последовательности соответствует обычному порядку следования элементов в изучаемой конструкции, т.е. со связкой, предшествующей предложному обороту, и без слов, разрывающих стык между связкой и предлогом. Нельзя исключить другой порядок следования, но его относительная частотность, скорее всего, ничтожно низка. ${ }^{22}$ Наверное, нам «ускользнуло» неизвестное количество примеров, в которых между связкой и предлогом появляется наречие чеш. jiz / пол. już 'уже', которое можно заметить довольно часто (ср. пол. Byli już po egzaminie; Było już po kłopocie). То же самое касается других наречий, например пол. wtedy 'тогда', właśnie 'как раз' (ср. Jan byt wtedy po operacji 'Ян тогда (только что) прошел операцию'). Но нет основания полагать, что учет таких вхождений в корпусах изменил бы значительно распределение между личным и безличным типами или между отдельными группами, которые мы обсудим ниже.

\footnotetext{
${ }^{22}$ Обратный порядок следования в принципе мог бы быть обусловлен выделением ремы (comment) или темы (topic). Ср., например, придуманные польские примеры: Po lampce wina (to) Jacek już byt, gdy spotkał na ulicy znajomego (i poszedt z nim na piwo) ₹ 'Что до бокала вина, то Яцек его уже выпил, когда на улице встретил знакомого (и пошел с ним выпить пиво)' ( $\rightarrow$ выделенная тема), To już po rozwodzie była Małgosia, kiedy poznała drugiego męża 'Это уже после развода была Малгося, когда познакомилась со вторым мужем’ ( $\rightarrow$ выделенная рема). Такие примеры звучат довольно искусственно и по меньшей мере требуют особого контекста. Нам неизвестен ни один такой реальный пример.
} 
Здесь уместно также коснуться трудных случаев отграничения предложного результатива от конструкций подобных, но по сути разных. Из рассмотрения мы исключили устойчивые сочетания типа чеш. není ani stopy (po něčem / po někom), пол. śladu nie było (ро czymś / kimś) 'следа не осталось (от чего / кого)'; ср.:

(63a) ... po dwóch dniach śladu nie bylo po fląderkach. Nie wszyscy się jednak zatapali (...).

... через два дня следа не осталось по камбалам. Но не все засекли... (APM; chefpaul.net)

(63b) Byl jsem tam dvakrát a není tam po ní ani stopy.

'Я там был дважды, а по ней там следа не осталось.'

(ABM: brokilon.cz)

Эти выражения напоминают второй безличный тип предложного результатива, и его смысл также сводится к указанию на исчезновение (уничтожение) личного или предметного референта, занимающего валентность предлога ро 'после'. Однако отрицание при связке входит в состав самой конструкции, на равных правах с родительным падежом śladu, так что этот оборот следует расценить как отдельную, фразеологизированную единицу. Кроме того, сам предложный результатив при отрицании не встречается (см. §3).

Исключили мы также случаи эллипсиса подлежащего (64), случаи, в которых значение být / być равнялось лексическому глаголу типа 'появиться' или 'пребывать, находиться' (64-65), ${ }^{23}$ и многочисленные случаи, когда функцию подлежащего выполняло указательное местоимение в среднем роде (66). В последнем случае to служит своего рода ситуативной анафоре, относящейся к пропозициям, извлекаемым из непосредственно предыдущего контекста. Во всех этих случаях ро + NOUN $_{\text {Lос }}$ служит обстоятельством (а не предикатом). Cp. польские примеры:

(64) - W Rzymie go nie ma. Będzie po wakacjach. 'В Риме его нет. Будет после каникул.'

(NKJP; Urząd)

(65) - Kiedyś tradycyjnie prezenty byly po kolacji, ale wtedy wszystko było na szybko, dzieci niecierpliwiły się, kręciły się przy stole i nie mogły spokojnie zjeść.

Когда-то подарки по традиции передавались после ужина, но тогда все проделывалось быстро, дети выходили из терпения, вертелись у стола и не могли спокойно съесть.'

(Gazeta Krakowska, 2004)

\footnotetext{
23 На принципиально другую синтаксическую структуру этих типов предложений указывал также Левицки (Lewicki 1973: 201-202).

Славистика XXII/1 (2018)
} 
(66) Kim jest Roger Jegorowicz? Spotkaliśmy się znowu. Ale to byto po przetomie.

'Кто такой Роджер Егорович? Мы встретились опять. Но это было после перелома.'

(NKJP; W. Stamm: Czarna matka, 2008)

Далее мы отвергли случаи, в которых подлежащее (как правило, неодушевленное) выступает как объект наследия, а предлог управляет существительным, называющим лицо, к которому этот объект принадлежал; ср. чешский пример:

Di̊m je po mamince.

‘Дом унаследован от мамы’ (досл. ‘Дом после мамы').

Этот синтаксический образец реализуется также с одушевленным существительным, но тогда «наследие» равняется родству; ср. польский пример из Левицкого (Lewicki 1973: 144):

$$
\begin{aligned}
& \text { Chtopiec byt po Jerzym. } \\
& \text { 'Мальчик был сыном Юрия.' }
\end{aligned}
$$

С синтаксической точки зрения такие примеры совпадают с личным типом предложного результатива, однако в данном случае предложный оборот не выражает какую-либо предшествующую ситуацию (или ее участника), а только приписывает определенный «наследственный» признак. Здесь не указывается на смену новой ситуации и причинно-следственную связь (см. компоненты (i-ii) в толкованиях, обоснованных в §3). Соответственно семантика не результативна, а просто стативна.

Больше всего трудностей доставляло множество безличных предложений, в которых группа рo $+\mathrm{NOUN}_{\text {เос }}$ просто выражала время суток или года. Ср. предложения под (69), в которых просто обозначается время, с примерами под (7071), в которых указание времени имплицирует изменение внешних условий, а связка уточняет время вытекающего из этого изменения нового состояния. Так происходило в частности, когда единица времени имела при себе определение, уточняющее, чем был «заполнен» соответствующий интервал (cp. 70c), или она метонимически отсылала к известным политическим событиям (ср. 71):

\section{польский}

(69) Było po drugiej w nocy. Jest po pótnocy.
'Было после двух часов ночи.'

'Уже за полночь.'

(70a) Nocą przymrozki i już może być po zbiorach, zamiast arbuzów popadną się same badyle!

'Ночью бывают заморозки, и может случиться так, что весь урожай пропадет, вместо арбузов нам останутся одни стебли!'

(NKJP; Wielbłąd na stepie, 1978) 
(70b) Delegaci obradują, jedzą i śpią w trzygwiazdkowym hotelu Polonez. „S“ zarezerwowała 390 miejsc. Podobno dostała od dyrekcji rabat (jest po sezonie). Delegaci mogą słuchać debaty w sali obrad lub w swoich pokojach, bowiem zjazd transmituje hotelowa telewizja.

‘Депутаты заседают, едят и спят в трехзвездочной гостинице Полонез. «S» забронировала 390 мест. Говорят, что она получила от администрации скидку (сезон уже прошел). Депутаты могут слушать прения в зале заседаний или в своих номерах, так как съезд транслируется по телевидению гостиницы.'

(NKJP; Gazeta Wyborcza, 1997)

(70c) A kilka lat później, kiedy Jedynak już byt po roku internowania $i$ działał $w$ podziemiu jako szef Regionu Śląsko-Dąbrowskiego, razem stworzyliśmy miesięcznik , Górnik Polski “.

'А несколько дней позже, когда Едынак уже прошел год интернирования и действовал в подземелье как шеф Силезско-Домбровского Района, мы вместе создали ежемесячник «Польский шахтер».'

(NKJP; Górnik Polski, 2005)

(70d) W październiku nad Polska przelatuje najwięcej gatunków, ale pod koniec listopada już jest po przelotach. Lasy i taki robia sie jakby martwe.

'В октябре над Польшей пролетает больше видов птиц, но под конец ноября перелетный сезон уже проходит. Леса и луга словно мертвеют.'

(NKJP; Gazeta Wyborcza)

\section{чешский}

(71) Ve státním vatikánském sekretariátu mi doporučili, abych si požádal o československý pas. Dostal jsem ho, když už bylo po srpnu. V roce 1969 jsem ještě stihl na pár dní navštívit otce a rok nato mě pustili na jeho pohřeb.

'В секретариате ватиканского государства мне поручили, чтобы я постарался получить паспорт Чехословакии. Я его получил, когда август уже был позади. В 1969 году я еще успел посетить отца, а через год меня пустили на его похороны.'

(SYN2015; Proti zlému krompáč a lopata)

В анализ мы включили случаи типа (70-71), но не типа (69). Спорны были примеры с обозначением праздников; ср. польские примеры:

(72a) A my jesteśmy po tragedii ukrzyżowania Jezusa, po zaniesieniu Jego ciała do grobu, po Jego zmartwychwstaniu $i$ wniebowstapieniu, po zesłaniu Jego Ducha na apostołów. A my jesteśmy po Wielkim Piątku, Wielkiej Sobocie, Wielkiej Niedzieli. A my jesteśmy już po Zesłaniu Ducha Świętego.

'А мы прошли трагедию распятия Христа, знаем, как Его тело занесли в могилу, как Он воскрес и вознесся в небеса, как Его дух был послан апостолам. А мы уже прошли Великую Пятницу, Великую Субботу, Великое Воскресенье. А мы уже знаем о Сослании Святого Духа.'

(NKJP; Zamyślenia, 1998) 
(72b) Na droge w Stanach Zjednoczonych spadło tysiace martwych ptaków. Akurat byto po Sylwestrze, więc wyjaśniono, że najprawdopodobniej zabily je fajerwerki.

'На дороги США с неба упало несколько тысяч мертвых птиц. Это произошло сразу же после Нового года, и, как выяснилось, скорее всего они стали жертвами праздничных фейерверков.'

(APM; superfakty.pl)

Мы решили включить их в число анализируемой выборки на тех же правах, что и примеры в (70-71).

\section{2. Общие результаты}

Общее количество примеров, полученных по запросу být / być + po + $\mathrm{NOUN}_{\text {เос }}$ было подвергнуто многократной основательной «чистке». ${ }^{24}$ Сумма примеров, представляющих предложный результатив (личный и безличный типы), в итоге составляла 1.137 примеров по польскому языку и 1.820 примеров по чешскому языку. Распределение общей совокупности примеров на использованные корпуса подается в следующей таблице; в ней также указывается относительная частотность (= количество вхождений на миллион словоформ / i.p.m., items per million):

Таблица 1: Общая частотность предложного результатива в польских и чешских корпусах

\begin{tabular}{|c|c|c|c|c|}
\hline \multirow[t]{2}{*}{ польский } & \multicolumn{2}{|c|}{$\begin{array}{l}\text { NKJP } \\
\text { (240.192.461 словоформа) }\end{array}$} & \multicolumn{2}{|c|}{$\begin{array}{l}\text { АРМ } \\
\text { (109.947.123 словоформы) }\end{array}$} \\
\hline & 509 & 7,49 i.p.m.* & 623 & 5,66 i.p.m \\
\hline \multirow[t]{2}{*}{ чешский } & \multicolumn{2}{|c|}{$\begin{array}{l}\text { SYN2015 } \\
\text { (120.748.715 словоформ) }\end{array}$} & \multicolumn{2}{|c|}{$\begin{array}{l}\text { АВМ } \\
\text { (120.139.611 словоформ) }\end{array}$} \\
\hline & 760 & 6,29 i.p.m. & 1.056 & 8,78 i.p.m \\
\hline
\end{tabular}

Сравнение показателей по относительной частотности обнаруживает, что предложный результатив встречается в пределе от 5 до 9 раз на миллион сло-

* Примечание: Относительную частотность для выборки из NKJP пришлось оценить посредством экстраполяции, потому что поисковая система Pelcra «выдала» только 5.001 пример, хотя и показывала, что во всем корпусе имеется 17.690 соответствий нашему «сырому» запросу. Экстраполяцию мы провели следующим образом: из 5.001 примера были отброшены все неподходящие примеры, а таких оказалось всего 509 (они впоследствии и подверглись анализу). 17.690 мы умножили на коэффициент из 509/5.001 ( $\approx 0.1)$, что дало 1.800 примеров. Это число мы поделили на общее количество словоформ (240.192.461), так что в результате мы получили 7,49 примера на миллион словоформ при учете всей совокупности.

24 За помощь в подготовке корпусного материала мы приносим свою благодарность Евгению Кравченко. 
воформ, так что в общем и целом он не особенно частотен. Далее, сравнение относительных частотностей показывает, что - в рамках указанного предела между собой различаются не столько польский и чешский языки, сколько их корпуса. Трудно сказать, почему в корпусах Araneum (ABM и APM) суммы по польской и чешской частям обнаруживают бо́льший отрыв друг от друга, чем национальные корпуса (NKJP и SYN2015). Корпуса Araneum состоят из текстов, которые собирались по источникам интернета; среди них большие доли приходятся на заявки и разные жанры рекламы, с одной стороны, и на блоги, с другой. То есть, в основном корпуса Araneum складываются из коротких текстов. Но вряд ли это выясняет разницу в частотности. Заметнее на результаты нашего запроса влияет упомянутая жанровая принадлежность (см. ниже).

В следующей таблице указывается распределение конструкции по личному и безличному типам, причем под безличным типом мы здесь объединили оба его варианта, разведенных в §3.2.

Таблица 2: Распределение по личному и безличному типам

\begin{tabular}{|l|c|c|c|c|}
\hline польский & всего & личный тип & безличный тип & \% безличный тип \\
\hline AРM & 622 & 490 & 133 & $21 \%$ \\
\hline NKJP & 515 & 275 & 234 & $45 \%$ \\
\hline чешский & всего & личный тип & безличный тип & \% безличный тип \\
\hline ABM & 1056 & 512 & 544 & $51 \%$ \\
\hline SYN2015 & 760 & 198 & 562 & $73 \%$ \\
\hline
\end{tabular}

На основании этой таблицы сразу видно, что в чешском языке безличный тип на уровне текста намного более частотен, чем в польском языке. Это верно в первую очередь по отношению к сопоставимым корпусам, т.е. к национальным корпусам между собой и соответственно к корпусам Araneum. Можно возразить, что особенно между польскими корпусами обнаруживаются значительные колебания, а также - что в обоих языках доля безличного типа меньше в корпусе Araneum, т.е. в «интернетовских» текстах. Частичным разъяснением может послужить факт, что в рекламных текстах очень многочисленны случаи личного типа чеш. Byt je po rekonstrukci, пол. Samochód jest po naprawie.

Больше внимания заслуживает следующее наблюдение: по табл. 2 больше всего друг от друга отличаются процентные доли польского корпуса АРМ и чешского SYN2015; а эти два корпуса обнаруживают самую низкую относительную частотность предложного результатива в целом (см. Табл. 1). Напротив, доля безличного типа в польском национальном корпусе сравнительно мало отличается от доли в чешском корпусе ABM; эти два корпуса обладают самой высокой относительной частотностью предложного результатива (Табл. 1). Напрашивается предположение, что, чем больше относительная частотность предложного результатива в целом, тем вероятнее, что распределение по личному и безличному типам стремится к выравнению. Такой тезис мы здесь проверить не можем, так что оставляем его на более углубленное исследование.

Славистика XXII/1 (2018) 
Теперь мы переходим к более подробному обсуждению сходств и различий между чешским и польским предложным результативом.

\section{3. Результаты анализа выборок польского и чешского языка}

Оба языка сходятся в том, что доля настоящих отглагольных существительных (nomina actionis), занимающих валентность предлога, крайне мала. Эти существительные имеют регулярный суффикс чеш. $\{n i / t i\}$, пол. \{nie/cie\}. В польской выборке нашлось всего 10 таких примеров $(+3$ сомнительных примера с существительным przestuchanie в NKJP и 5 с другими возможно лексикализованными существительными), а в чешском не было найдено ни одного примеpa; больше всего nomen actionis напоминало только существительное zlomenina ‘перелом' в примере (75): 25

\section{польский}

(73) Witam, jestem po rozstaniu z osoba [z] która żytem 12 lat.

'Здравствуйте, я пережил расставание с человеком, с которым жил 12 лет.' (APM; remitent.pl)

(74) Proszę zwrócić uwagę, w którym momencie głosowań jesteśmy w tej chwili. Jesteśmy po przyjęciu albo odrzuceniu określonych poprawek, nie ma żadnych podstaw do reasumpcji tych glosowań. Jesteśmy przed ostatecznym glosowaniem.

'Обратите внимание, на каком этапе голосования мы находимся сейчас. Мы приняли или отвергли определенные поправки, нет основания, чтобы возвращаться к этому голосованию. Мы перед последним голосованием.'

(NKJP; Sprawozdanie stenograficzne z obrad Sejmu RP z dnia 26.06.1997, 2 kadencja, 110 posiedzenie, 3 dzień; 1997)

\section{чешский}

(75) Syn je po zlomenině nějaké nártové kostičky, má otoky, měl hluboký zánèttrombózu, bere léky na ředění krve.

'Сын сломал какую-то кость плюсны, у него отеки, глубокое воспаление, он принимает лекарства на разжижение крови.'

(ABM; jtvesely.txt.cz)

Соответственно дополнения отглагольных существительных реализуются крайне редко (ср. 74-75). Попутно отметим, что ввиду редкости отглагольных существительных в рассматриваемой конструкции такие существительные вряд ли могли дать толчок к распространению предложного результатива.

Кажется, что данной особенностью и исчерпываются главные сходства меж-

${ }^{25}$ В (Giger 2003: 25) приводится пример, соответствующий безличному типу: «Trhni si nožkou, je po vyučování», zamumlal jsem. '«Иди прочь, твой срок обучения закончился», пробормотал я.' Однако можно усомниться в том, что vуuс̌оvání является настоящим, а не лексикализованным отглагольным существительным (указывается не на сам процесс или событие, а на промежуток времени, занятый данным процессом). 
ду обоими языками (кроме тривиального соответствия основным толкованиям, представленным в §3). Наш сопоставительный анализ выявил большие различия в распределении личного и безличного типов, а также в плане лексического «заполнения» предложного оборота.

О расхождениях в отношении личного и безличного типов мы уже упоминали в §3. Сначала о личном типе. Практически только в польском языке метонимический сдвиг, ведущий от предшествующей ситуации или события к состоянию, на которое имплицитно наводит предложный результатив, осложняется объектом, с которым связано событие (cp. Jesteśmy po dwóch piwach ₹ 'Мы после выпивки двух пив', т.е. 'Мы выпили два пива'); в чешском языке такие случаи не попались (см. §3.1). Относительно безличного типа мы заметили, что для «уничтожительного» варианта в чешском языке не встретилось ни одного примера с объектным именем (cp. Upadta mu siatka i bylo po jajkach 'У него упал пакет и яйца разбились [つ яиц больше не было]'); предложный оборот заполнялся только местоимениями или существительными, называющими человека (людей); см. §3.2.2. Только что сделанные наблюдения заставляют думать, что диапазон существительных, выступающих в предложном результативе, в польском языке шире, чем в чешском. Или наоборот: в чешском языке ограничения на образование предложного результатива на порядок больше, чем в польском, потому что в чешском избегается использование целых двух тематических классов существительных в этой конструкции. Если это рассуждение корректно, то в польском языке продуктивность предложного результатива, скорее всего, выше, чем в чешском.

К последнему пункту мы еще вернемся, но тем самым мы уже перешли к различиям по лексическому заполнению. В этом плане чешский и польский языки сходятся в том, что в выборках отмечается всего лишь горстка чрезвычайно частотных лексем (см. Табл. 4), которой противостоит громадный ряд лексем, вошедших в конструкцию (предикативный предложный оборот с данным значением) только по нескольку раз или всего лишь один раз. Следующие таблицы показывают распределение лексем по группам частотности (в скобках указано количество вхождений в соответствующей выборке), однако только для корпусов Araneum, поскольку для прямых сопоставлений они нам показались лучше приспособленными (в смысле жанров, объему и т.д.).

Таблица 3a: Группы лексем по частотности: личный тип (ABM, АРM)

\begin{tabular}{|c|c|c|c|c|c|c|}
\cline { 2 - 6 } \multicolumn{1}{c|}{} & \multirow{2}{*}{$\begin{array}{c}\text { общее кол. } \\
\text { лексем (types) }\end{array}$} & \multicolumn{4}{|c|}{ частотность употребления в выборке } & \multirow{2}{*}{$\begin{array}{c}\% \\
\text { (token frequency) }\end{array}$} \\
\cline { 2 - 6 } \multicolumn{1}{c|}{} & $>10$ раз & $6-10$ раз & $2-5$ раз & 1 раз & $1-5$ раз \\
\hline чешский & $103(100 \%)$ & 5 & 3 & 27 & 68 & $92 \%$ \\
\hline польский & $207(100 \%)$ & 5 & 5 & 54 & 143 & $95 \%$ \\
\hline
\end{tabular}


Таблица 3б: Группы лексем по частотности: безличный тип (АВМ, АРМ)

\begin{tabular}{|c|c|c|c|c|c|c|}
\hline & \multirow{2}{*}{$\begin{array}{c}\text { общее кол. } \\
\text { лексем (types) }\end{array}$} & \multicolumn{4}{|c|}{$\begin{array}{c}\text { частотность употребления в выборке } \\
\text { (token frequency) }\end{array}$} & \multirow{2}{*}{$\begin{array}{c}\% \% \\
\text { лексем } \\
1-5 \text { раз }\end{array}$} \\
\hline & & $>10$ раз & $6-10$ раз & $2-5$ раз & 1 раз & \\
\hline & $216(100 \%)$ & 7 & 9 & 33 & 167 & $93 \%$ \\
\hline польский & $59(100 \%)$ & 2 & 2 & 8 & 47 & $93 \%$ \\
\hline
\end{tabular}

Видно, что относительное распределение на группы по частотности не обнаруживает особых различий между обоими языками и что подавляющее большинство лексем в выборках с предложным результативом выступило не чаще чем пять раз. Это наблюдение говорит в пользу высокой продуктивности предложного результатива, а это особенно замечательно на фоне низкой частотности предложного результатива в целом (см. Табл. 1).

Таблица 4 перечисляет лексемы, которые найдены более 10 раз, для всех корпусов отдельно.

Таблица 4: Самые частотные лексемы

\begin{tabular}{|l|l|l|}
\cline { 2 - 3 } \multicolumn{1}{c|}{} & \multicolumn{1}{|c|}{ личный тип } & \multicolumn{1}{c|}{ безличный тип } \\
\hline \multirow{5}{*}{ пешский } & $\begin{array}{l}\text { SYN2015: } \\
\text { пmrt (110), operace (43) }\end{array}$ & $\begin{array}{l}\text { SYN2015: v̌se (245), on (56), } \\
\text { válka (19), zápas (13) }\end{array}$ \\
\cline { 2 - 3 } & $\begin{array}{l}\text { ABM: rekonstrukce (189), } \\
\text { operace (71), smrt (38), } \\
\text { revitalizace (29), porod (12) }\end{array}$ & $\begin{array}{l}\text { ABM: vše (106), problém (42), } \\
\text { on (19), válka (15), problémy } \\
(13), \text { dešt' (12), zápas (11) }\end{array}$ \\
\hline \multirow{3}{*}{} & NKJP: & NKJP: \\
& rozwód (18), operacja (12) & wszystko (124) \\
\cline { 2 - 3 } & APM: remont (49), operacja (29), & APM: \\
& rozwód (29), studia (27), ślub (16) & wszystko (36), sprawa (14) \\
\hline
\end{tabular}

В обоих языках выражение универсального квантора (чеш. vše, пол. wszyst$k o$ ) с большим отрывом является безраздельным «лидером» по частотности в безличном типе. В личном типе удивляет чрезмерно высокая частотность слова smrt 'смерть' в чешском; видимо, $X$ je po smrti просто лексикализовалось в значении 'Х мертв / умер'. Кроме того, для обоих языков в корпусе из Araneum нашлось высокое число примеров с существительными, относящимися к ремонту квартиры; этот курьез легко объяснить чрезмерной представленностью мелких заявок в текстах, вошедших в эти корпуса (см. выше). Кроме этого, среди наиболее частотных лексем в обоих языках мы находим чеш. operace / пол. operacja, но только в чешском эта лексема особенно выбивается. Этот 
факт может быть случайным, по крайней мере он не поддерживается другими лексемами, связанными со сферой здоровья и здравоохранения; а эта тематическая сфера для обоих языков в принципе хорошо представлена в предложном результативе.

На самом деле, главные расхождения между чешским и польским языками связаны с тем, какие лексемы действительно заполняют валентность предлога ро. Как раз среди менее частотных лексем - т.е. в их основной массе - часто наблюдаются несоответствия, которые говорят о довольно различном распределении как по отдельным лексемам, так и по целым тематическим классам. Отсутствие соответствий проявляется двумя (на первый взгляд противоположными) способами: с одной стороны, при сравнении конкретных лексем, заполняющих валентность предлога ро, наблюдается мало пересечений; то есть, когда мы вникаем в то, какие лексемы употребляются в одном из языков, мы замечаем, что эквивалентов в другом языке часто найти нельзя. С другой стороны, когда мы находим когнатные выражения, их конвенциональная (или просто преобладающая) интерпретация разная. Первое наблюдение хорошо вписывается в соображения о продуктивности предложного результатива, которую мы затронем ниже. Последнее наблюдение, напротив, показывает, что предложный результатив предоставляет некий стабильный каркас конструкции, который в зависимости от конкретного лексического заполнения может принимать более или менее идиоматичное значение.

Сначала мы проиллюстрируем расхождения по интерпретации когнатных, или тематически близких; выражений, занимающих место после предлога $p o$, на одном из наиболее ярких примеров, которые нам встретились в материалах. Поскольку мы здесь останавливаемся на возможных интерпретациях одного и того же выражения (после предлога ро), то для этого выражения нам пришлось выйти за пределы определенных выше выборок; для чешского языка мы дополнительно воспользовались данными из более объемного корпуса SYN4. (Разумеется, в наши подсчеты эти примеры включены не были.) Итак, сравним чеш. po škole с пол. po szkole. В то время как пол. po szkole стабильно и даже исключительно относится к состоянию после получения образования (и соответственно диплома) (76), чеш. po škole имеет бо́льший диапазон употреблений: оно может значить то же, что по-польски (77a), но также указывать на кратковременное состояние после школьных занятий в какой-то определенный день (77b); преобладают однако употребления po škole, когда ученику пришлось отсидеть «штрафной урок» (ср. нем. nachsitzen); ср. (77c). Последнее значение оказывается особенно идиоматизированным для чешского языка и отсутствует у польского когнатного выражения:

\section{польский}

(76) Ja jestem po szkole $w$ Lazach (rocznik 2009) i jestem dumny że ... 'Я окончил школу в Лазах (выпуск 2009 года) и горжусь что...'

(APM; lazowianie.pl) 


\section{чешский}

(77a) Saháme po hodně mladých lidech, kteř́ jsou po škole s minimální praxí.

'Мы оглядываемся на довольно молодых людей, которые (только что) закончили школу и имеют мало опыта.'

(SYN4; Mladá fronta DNES)

(77b) Těším se, až bude po škole a budu mít volno. Sejdeme se s kamarádem a puijdeme se asi jen tak projit po centru Brna.

'Я рад, когда уроки на сегодня будут закончены [досл. 'пока будет после школы'] и у меня будет свободное время. Мы встретимся с коллегой и пойдем, чтобы просто так пройтись по центру Брно.'

(SYN4; Deníky Moravia)

(77c) A pyšně připsal, že nikdy nebyl po škole.

'И он гордо дописал, что никогда ему не приходилось отсиживать штрафной урок.'

(SYN4; Instinkt)

Пол. po szkole вписывается в разряд, который по аналогии создают употребляемые в предложном результативе существительные, обозначающие учреждения, направления или предметы образования, а также «единицы», задающие блоки обучения, как напр. kurs, seminarium или $n$-ty rok studiów; cp.

(78) Jej mąż jest po ogólniaku i nie może znaleźć pracy.

'Ее муж окончил общий лицей и не может найти работу.'

(NKJP; Gazeta Wyborcza)

(79) Znam wiele dziewczyn z HE, które sa po germanistyce.

' Я знаю много девушек с НЕ, которые закончили германистику.'

(APM; opiekunki24.pl)

В польском языке этот тип переноса задает целый тематический класс. Подобные примеры встречаются тоже в чешском (ср. 77а и 80), но заметно реже (на уровне текста) и не так систематически (на уровне лексем) как по-польски:

(80) Snowboard'áci jsou po kurzu.

'Сноубордисты прошли курс.'

(SYN4; Deníky Moravia)

Подытожим: когнатные, или тематически близкие, существительные, выступающие в предложном результативе, могут вызывать разные частные интерпретации, которые обусловлены разными типами метонимического переноса; вслед за этим, разные интерпретации связаны с разным объемом интервалов имплицируемых состояний. При этом важно, что в рамках предложного результатива конкретный метонимический перенос закреплен за данным существительным не окказионально, а конвенционально. 
Обратимся теперь к обратной стороне лексического заполнения, т.е. к первому из выше отмеченных различий по лексическому заполнению. В наших выборках лексемы, заполняющие валентность предлога, часто не пересекаются и объединяются они в разные тематические группы. Такое наблюдение можно сделать, если в одном языке провести классификацию примеров из выборки по тематическим классам (наподобие подразделениям в тезаурусных словарях). Подобное подразделение в 23 группы (из области пищи, образования, спорта, здоровья, права, семейных отношений, исторических событий и т.п.) мы провели для польского языка. Конечно, такая классификация, опирающаяся на интуитивное понимание предметных областей, не может быть полностью дополнительной, пересечения между ними и спорные случаи не исключены. Однако первый опыт показал, что такое деление возможно с довольно большой долей однозначности. ${ }^{26}$

Важно другое, а именно: деление, проведенное на польской выборке, плохо подошло для чешской выборки; если чешские примеры «рассортировать» по группам, введенным для польской выборки, то относительные частотности почти всех групп в обоих языках заметно отличаются. Соответствия мы наблюдали только у безличного варианта: личные местоимения и особенно кванторное 'всё' забирают огромную долю всех примеров, причем местоимения по «уничтожительному» значению (см. §3.2.2), а кванторное выражение по первому значению безличного типа (см. §3.2.1). А числовые соотношения между группами, осуществляющими личный вариант, друг от друга отличаются намного больше. При условии, что наши выборки можно признать достаточно представительными, эти наблюдения позволяют выдвинуть осторожную гипотезу, что предложный результатив - по меньшей мере его личный тип - в чешском и польском языках по большому счету проявляют достаточно разные предпочтения в плане лексического заполнения и предметных областей, «обслуживаемых» этой конструкцией. По большому счету для чешского языка в личном типе предложного результатива характерны только области ремонта (если подлежащее - квартира и т.п.) и операции (его подлежащее - человек).

Напоследок, различия относительно лексического заполнения отражаются также в отчасти разной продуктивности предложного результатива. Продуктивность и вопрос о том, какими параметрами ее лучше всего следует описывать, до сих пор служат предметом споров среди специалистов (см. Baayen 2009; Zeldes 2012 и др.). Однако достаточно надежным показателем продуктивности можно признать соотношение между количеством единиц (= types), т.е. лексем из некоего открытого класса, способных занять определенный «слот» в той или иной конструкции, и частотностью, с которой каждая отдельная из этих единиц в реальном дискурсе встречается в соответствующей позиции (= tokens). Это соотношение создает коэффициент, так наз. type/token ratio. Чем больше найдется лексем, занимающих определенный «слот» конструкции только по нескольку раз или по одному разу (hapax legomena) в выборке, тем больше растет этот коэффициент и тем выше будет продуктивность. Применительно к предложному результативу это означает, что рост общего ко-

\footnotetext{
${ }^{26}$ По соображениям места результаты сопоставления по тематическим группам будут опубликованы в другой работе.
}

Славистика XXII/1 (2018) 
личества лексем, которые в выборке встречаются в указанной позиции только изредка, повышает type/token ratio, а это, тем самым, служит показателем продуктивности этой конструкции. С этой точки зрения антагонистом продуктивности является лексикализация (включая сюда и фразеологизацию): заметный рост частотности в речи только считанного количества лексем ведет к очень низкому коэффициенту (type/token ratio); он означает «закостенение» этих лексем в данной конструкции и уменьшение ее «прозрачности», а также спад продуктивности конструкции в целом.

По нашим выборкам получается следующее. С одной стороны, в польском языке коэффициенты type/token личного типа заметно выше, чем в чешском, т.е. в польском языке гораздо больше лексического разнообразия. С другой стороны, коэффициенты type/token по безличному типу между обоими языками более выравнены (по сравнению с личным типом), но по ним большее лексическое разнообразие наблюдается скорее, и более стабильно, в чешском языке.

Таблицы 5: Соотношение между лексемами (types) и их реализацией в дискрусе (tokens)

NKJP / SYN2015

\begin{tabular}{|c|c|c|c|c|c|c|c|}
\hline польский & types & tokens & $\begin{array}{c}\text { type/ } \\
\text { token } \\
\text { ratio }\end{array}$ & чешский & types & tokens & $\begin{array}{c}\text { type/ } \\
\text { token } \\
\text { ratio }\end{array}$ \\
\hline личн. & 129 & 275 & 0,46 & личн. & 29 & 198 & 0,14 \\
\hline безл. & 65 & 234 & 0,27 & безл. & 124 & 562 & 0,22 \\
\hline
\end{tabular}

Araneum (APM / ABM)

\begin{tabular}{|c|c|c|c|c|c|c|c|}
\hline польский & types & tokens & $\begin{array}{c}\text { type/ } \\
\text { token } \\
\text { ratio }\end{array}$ & чешский & types & tokens & $\begin{array}{c}\text { type/ } \\
\text { token } \\
\text { ratio }\end{array}$ \\
\hline личн. & 207 & 490 & 0,42 & личн. & 103 & 512 & 0,22 \\
\hline безл. & 59 & 133 & 0,44 & безл. & 216 & 544 & 0,39 \\
\hline
\end{tabular}

Такой вывод частично согласуется с высказанным выше предположением о том, что продуктивность предложного результатива в польском языке, скорее всего, выше, чем в чешском, поскольку в чешском языке предметные имена практически не используются ни в личном типе, ни в «уничтожительном» значении безличного типа. Если предметные имена «отпадают», то сужению диапазона лексем, занимающих позицию после предлога, теоретически может противодействовать только более широкая, чем в польском, палитра лексем, относящихся к событийным именам (включая обозначения процессов, например práce 'работа'). Местоимения, столь частотные в «уничтожительном» значении, и кванторные слова, который занимают верхнюю позицию по частотно- 
сти в тексте для первого значения безличной конструкции, представляют собой замкнутые и весьма малочисленные классы, а класс существительных общего значения, выступающих в первом значении безличного типа, тоже вряд ли может значительно расшириться (если не окказионально, как в примере 48 с существительным тесz).

\section{5. Выводы}

Пора подытожить наблюдения о проведенном нами первом опыте изучения предложного оборота $b y ́ t /$ być $+p o+\mathrm{NOUN}_{\text {Lос }}$ в предикативном употреблении. Чешский и польский языки были выбраны потому, что уже первый обзор славянского материала (а также материала других европейских языков) делает очевидным, что данная конструкция в этих языках выделяется достаточно отчетливо. Стимулом послужил также факт ее почти полной неизученности и желание уточнить ее интуитивно улавливаемые свойства. Кроме более систематического анализа семантики этой конструкции мы задались целью присмотреться к тому, как она реально используется в речи. Для этой цели мы обратились к электронным корпусам. Такой комплексный подход оправдан тем, что, по нашему убеждению, семантические свойства той или иной конструкции (или другой единицы языка) нельзя оценивать в отрыве от свойств, которые проявляются в речи и которые выявляются только при рассмотрении более масштабных данных; эти свойства - распределение и продуктивность (см. ниже).

Начнем с семантики выбранной конструкции. Мы ее причислили к результативам, потому что она указывает на состояние, наступившее после некоторой смены вследствие событий, связанных с референтом, который называет существительное, управляемое предлогом ро 'после'. Как с любым результативом, существенно, что устанавливается причинно-следственная связь между событием, вводящим новое состояние, и этим новым состоянием. То есть, предикативный оборот не указывает просто на стативную ситауцию, как это имеет место, например, когда называется время суток (пол. Byto po trzeciej $\approx$ 'Было в четвертом часу / Пробило три часа'). По этой причине изучаемый оборот мы окрестили 'предложным результативом'. Однако в отличие от обычных результативов состояние, актуальное в момент, на который ссылает время связки, не называется прямо, а имплицируется. То есть, это состояние находится под ассерцией, но участникам коммуникации приходится устанавливать связь между предшествующей ситуацией (или событием, которое заканчивает эту ситуацию) и актуальным состоянием на основе метонимических отношений между тем, что называется в предложном обороте, и этим же состоянием. Например, пол. Oni sa po rozwodzie (досл. 'Они после развода') косвенно указывает на состояние, наступившее после развода, хотя существительное в предложном обороте само по себе последствия развода не называет, а характер состояния не уточняется. Вместе с тем, сдвиг, нужный для интерпретации, не сводится просто к тривиальному для результативов временно́му сдвигу между предшествующим событием и следующим за ним состоянием (ср. Открыли дверь [предельное событие] > Дверь открыта [результирующее состояние]); к этому сдвигу присоединяются качественно иные импликации (напр. пол. po porodzie: рождение ребенка > (а) новые социальные обязательства / (б) изменения в ор- 
ганизме женщины, рожавшей ребенка). Эта особенность предложного результатива хорошо согласуется с фактом, что в чешском и польском языках в этой конструкции практически отсутствуют настоящие отглагольные существительные (хотя они в принципе возможны).

Метонимическая связь (импликация) осложняется, если в предложной группе используется не событийное имя, а существительное с конкретным референтом (в широком смысле), напр. пол. Jesteśmy po piwie / po obfitym bigosie (досл. 'Мы после пива / после изобильного бигоса'). В таком случае для установления связи с результирующим состоянием необходим еще один дополнительный метонимический перенос (в данном случае: порция еды или питья > прием этой порции > состояние после приема порции). В польском языке такие случаи довольно обычны, тогда как по-чешски они встречаются лишь единичными примерами.

Важно отметить, что переносы (импликатуры) - как более простые, так и осложненные - обладают разной степенью конвенциональности, а эту степень, видимо, приходится устанавливать отдельно для каждой лексемы, занимающей валентность предлога.

Далее, для предикативной конструкции být / być + po +NOUN различать варианты с подлежащим (личный вариант) и без него (безличный вариант). Эти синтаксические варианты отличаются также семантически, а безличный вариант подразделяется на два значения. Значения безличного варианта характеризуются по сути дополнительным распределением онтологических групп существительных, занимающих валентность предлога: в одном значении выступают по сути только событийные имена (и это значение ближе к значению личного варианта), в другом значении эту валентность заполняют личные местоимения, предметные имена и личные имена (а также изредка, существительные, обозначающие учреждения, предприятия и т.п., которые на правах метонимии ссылают на совокупности людей), а намного реже - существительные, называющие состояния (типа любовь, согласие и т.п.) и другие абстрактные величины (напр. валюту). Смысл этого значения сводится к утверждению о том, что референта, названного этим существительным, больше нет. Разграничение обоих значений безличного варианта бывает трудным, если в нем употребляется кванторное выражение 'всё' (чеш. po všem, пол. po wszystkim), которое оказывается наиболее частотным «лексическим заполнителем» конструкции, или семантически опустевшее выражение типа чеш. ро problému, po parádě, пол. po sprawie, po herbacie. Для этих последних бывает характерен эмоциональный оттенок, а также дискурсивная функция замыкания «абзацных» единиц текста.

Упомянутые свойства предикативной конструкции být / być + po +NOUN ${ }_{\text {Lоc }}-$ прежде всего нетривиальные и в разной степени сконвенциализованные семантические сдвиги - объясняют, почему с этой конструкцией нельзя сопоставить

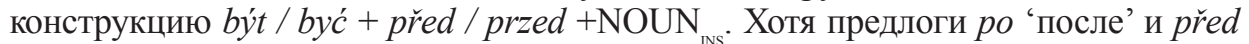
/ przed 'перед, до' обосновывают конверсивные отношения предшествования и следования, то регулярная (т.е. предсказуемая) симметрия между ними обнаруживается только, когда они употребляются как обстоятельства. В предикативном же употреблении между ними симметрии нет. Это объясняет факт, что конструкция být / być + před / przed +NOUN 
честве сказуемого встречается крайне редко, а если встречается, то со считанными единицами узкого лексического круга (типа экзамен, голосование) и только в личном варианте. Следовательно, предлоги ро 'после' и pred / przed ‘перед, до' в рамках предикативной конструкции нельзя признать аналогами друг друга.

Этот вывод связан с тем, что образцы, которые скрываются за конструкцией být / być + po +NOUN ${ }_{\text {เос }}$, не в полной мере семантически «прозрачны», т.е. выделенные выше значения не являются простой суммой значений их синтаксических составляющих. Вместе с тем эти образцы на уровне текста реализуются довольно редко, общая относительная частотность (на миллион словоформ) очень низка. Но помимо этого предложный результатив обладает определенной продуктивностью, причем разной для разных значений. Продуктивность уже становится осязаемой, если осознать, что больше чем $90 \%$ всех вхождений предложного результатива в корпусах приходится на лексемы, которые в этой конструкции выступают только от одного до пяти раз. Иными словами: круг лексем с большой частотностью очень узок, а между высоко- и низкочастотными лексемами практически нет переходной области. Далее, если считать достаточно надежным показателем продуктивности коэффициент из общего числа лексем, способных занимать валентность предлога, и частоты реализации предложного результатива в дискурсе (= type/token ratio), то оказывается, что личный и безличный варианты приходится оценивать отдельно. Хотя в чешском языке безличный тип в общем и целом гораздо более частотен, чем в польском, то в польском языке лексическое разнообразие заметно выше в личном варианте, а по безличному типу коэффициенты types/tokens между обоими языками отличаются в заметно меньшей степени.

Выводы, сделанные на основе корпусов, конечно, предварительны. В частности, следует выяснить отчасти значительные колебания частотностей между корпусами, а, выяснив их, стремиться к большей степени контроля над случайными факторами (как, например, непропорционально высокая доля отдельных лексем или тематических групп, обусловленная жанрами текстов), которые могут помешать при оценке продуктивности и лексического диапазона отдельных типов (или значений) предложного результатива, а также - контекстных условий, способствующих его употреблению. Следует однако подчеркнуть, что даже предварительные выводы как наши стали возможны только благодаря работе с корпусами. Корпуса незаменимы, когда изучаются такие свойства как продуктивность и, шире, распределение тех или иных конструкций в речи. При этом они служат не только как средство для подкрепления и иллюстрации выводов и гипотез, сформулированных заранее в отрыве от исследования выбранных феноменов в речи. Корпуса являются незаменимым средством для порождения гипотез - а именно гипотез о том, что нельзя установить невооруженным глазом и о чем вряд ли может догадаться даже опытный лингвист. Корпуса и способы их использования безусловно требуется совершенствовать, и к ним нужно относиться критически (так же как нужно совершенствовать и критически оценивать другие методы и орудия научной работы). Но важно осознавать, что существуют свойства языковых единиц, которые можно «ощупывать» и проверять лишь с помощью корпуса. Наш первый подход к предложному результативу показывает это довольно отчетливо.

Славистика XXII/1 (2018) 


\section{Использованная литература}

Байда, Виктор В. «Перфектные конструкции в ирландском языке». [В:] Т. А. Майсак, В. А. Плунгян, К. Р. Семенова (ред.) Исследования по теории грамматики, вып. 7: Типология перфекта [= Acta Linguistica Petropolitana, t. XII, č. 2]. Санкт-Петербург, 2016, $163-216$

Золотова, Галина А. Синтаксический словарь (Репертуар элементарных единиц русского синтаксиса). Москва: Наука, 1988.

Кириченко I. Н. (голов. ред.). Українсько-російський словник, т. III. Київ: Видавництво Академії наук УРСР, 1961.

Недялков, Владимир П., Сергей Е. Яхонтов. «Типология результативных конструкций». [В:] В. П. Недялков (ред.) Типология результативных конструкций (результатив, статив, пассив, перфект). Ленинград: Наука, 1983, 5-41.

Baayen, Harald. "Corpus Linguistics in Morphology: Morphological productivity". [In:] A. Lüdeling, M. Kytö (eds.) Corpus Linguistics. An International Handbook, vol. 2. Berlin, New York: Walter de Gruyter, 2009, 899-919.

Bertinetto, Pier Marco. "The Progressive in Romance, as Compared with English". [In:] Ö. Dahl (ed.) Tense and Aspect in the Languages of Europe. Berlin, New York: Mouton de Gruyter, 2000, 559-604.

Bloch, Oscar, Walther von Wartburg. Dictionnaire étymologique de la langue française. Paris: Presses universitaires de France, $1968^{5}$.

Dauzet, Albert. Dictionnaire étymologique de la langue française. Paris: Librairie Larousse, 1938.

Faska, Helmut. Pućnik po hornjoserbšćinje. Bautzen: Domowina, 2009.

Gamillschegg, Ernst. Etymologisches Wörterbuch der französischen Sprache. Heidelberg: Winter, $1969^{2}$.

Giger, Markus. Resultativa im modernen Tschechischen. Berlin, Bern, Frankfurt am Main, Wien etc.: Lang, 2003.

Grepl, Miroslav, Petr Karlík. Skladba češtiny. Olomouc: Votobia, 1998.

Grochowski, Maciej. "Ekwiwalencja funkcjonalna i semantyczna wykładników następstwa w wypowiedzeniu prostym i złożonym”. Studia z filologii polskiej i słowiańskiej 34, 1998: 43-53.

Heine, Bernd, Tania Kuteva. Language Contact and Grammatical Change. Cambridge etc.: Cambridge University Press, 2005.

Klebanowska, Barbara. "Przyimek po w znaczeniu czasowym". Prace Filologiczne 31, 1982: 97-102.

Kosek, Iwona. Przyczasownikowe frazy przyimkowo-nominalne w zdaniach współczesnego języka polskiego. Olsztyn: Wyd-wo Uniw-tu Warmińsko-Mazurskiego, 1999.

Lewicki, Andrzej Maria. "Orzecznik przyimkowy w polskim języku współczesnym”. Prace Filologiczne 24, 1973: 117-209.

Orlovský, Jozef. Slovenská syntax. Bratislava: Obzor, 1971³.

Petr, Jan et al. 1987. Mluvnice češtiny III. Praha: Academia, 1987.

Przybylska, Renata. "Znaczenia temporalne polskich przyimków". Polonica 11, 1985: 77-117.

Przybylska, Renata. Polisemia przyimków polskich w świetle semantyki kognitywnej. Kraków:

Universitas, 2002.

Robert, Paul. Dictionnaire alphabétique et analogique de la language française, t. I. Paris: Le Robert, $1985^{2}$.

Salińska, Dorota. "Cechy składniowe i semantyczne metatekstowych jednostek leksykalnych (z

segmentem i) zamykających wypowiedź”. Polonica 32/33, 2003: 269-290.

Šmilauer, Vladimír. Novočeská skladba. Praha: SPN, 1947¹ $1969^{3}$.

Tommola, Hannu. "On the Perfect in North Slavic". [In:] Ö. Dahl (ed.) Tense and Aspect in the Languages of Europe. Berlin, New York: Mouton de Gruyter, 2000, 441-478.

Toporišić, Jože. Slovenska slovnica. Ljubljana, Maribor: Založba Obzorja Maribor, 1976.

Trávníček, František. Mluvnice spisovné češtiny. 2. Skladba. Praha: Slovanské nakladatelství, 1951. 
Weiss, Daniel. Syntax und Semantik polnischer Partizipialkonstruktionen. Bern, Frankfurt am Main etc.: Lang, 1977.

Wiemer, Björn, Marku Giger. Resultativa in den nordslavischen und baltischen Sprachen (Bestandsaufnahme unter arealen und grammatikalisierungstheoretischen Gesichtspunkten). München, Newcastle: LINCOM Europa, 2005.

Zeldes, Amir. Productivity in Argument Selection (From Morphology to Syntax). Berlin, Boston: De Gruyter Mouton, 2012.

\section{Kopnyca}

Aranea: A Family of Comparable Gigaword Web Corpora. http://ucts.uniba.sk/aranea_about/ index.html.

ABM $=$ Araneum Bohemicum Minus.

APM = Araneum Polonicum Minus.

hotko. http://wiki.korpus.cz/doku.php/en:cnk:hotko

PELCRA. http://www.nkjp.uni.lodz.pl

prim-8.0. http://korpus.juls.savba.sk/prim(2d)8(2e)0_en.html

SYN4. http://wiki.korpus.cz/doku.php/en:cnk:syn:verze4

SYN2015. http://wiki.korpus.cz/doku.php/cnk:syn2015

Корпус української мови (КУМ): http://www.mova.info/corpus.aspx

Национальный корпус русского языка (НКРЯ): http://www.ruscorpora.ru/ 
Тилман Бергер, Бјорн Вимер

\section{ПРЕДЛОШКИ РЕЗУЛТАТИВ У ПОљСКОМ И ЧЕШКОМ ЈЕЗИКУ}

\section{Резиме}

У овом раду настојали смо да издвојимо основне оријентире за систематско проучавање предикатског израза са предлогом no: $b y ́ t / b y c ́$ + po $+\mathrm{NOUN}_{\text {เоc }}$. На општеевропском тлу ова конструкција је најуочљивија у пољском и чешком језику. Можемо је разматрати у оквиру грамема за које је у типологији општеприхваћен назив резултатив. (Могуће је и њено тумачење као експеријенцијалног перфекта, али засад то значење нисмо посебно издвајали.) Конструкција указује на стање које наступа после одређеног преокрета услед догађаја везаних за референта. Потоњи је означен именицом уз коју стоји предлог по у значењу 'после'. Успоставља се узрочно-последична веза између догађаја који уводи ново стање и самог насталог стања. Другим речима, предикатски израз у овом случају не одређује само статичку ситуацију, као што је то случај са сличном темпоралном конструкцијом (пол. Byto po trze$c i e j \approx$ 'Прошло је три'). Отуд проистиче и назив 'предлошки резултатив'. Међутим, за разлику од обичног резутатива, стање које је било актуелно у времену на које указује копула не номинује се, већ се имплицира: стање је у фокусу асерције, али учесници у комуникацији морају сами одредити однос између претходне ситуације (или догађаја којим се потоња завршава) и актуелним стањем полазећи од метонимијских односа између оног што именује предлошка конструкција и одговарајућег стања. Степен сложености метонимијског односа првенствено зависи од тога да ли именица у конструкцији именује догађај или стање (нпр.: развод, испит, грип, свађа), предмет (у ширем смислу, нпр.: ауто, кафа), човека или уопштени појам (нпр.: проблем, ствар). Осим тога, треба разликовати лични и безлични тип (уз даљу поделу потоњег), који су семантички неподударни. Издвојени типови су делимично условљени дијапазоном лексичког пуњења, које је веома неуједначено ако се посматра на текстуалном нивоу, чак и уколико се дистанцирамо од могућих лексикализованих типова конструкција попут пољ. Jest po wszystkim / чеш. Je po všem 'Све је свршено'. Управо на нивоу текста и лексичког пуњења запажамо разлике како између пољског и чешког језика међусобно тако и поредећи их са другим словенским и несловенским европским језицима. Стога смо посветили посебну пажњу расподели одређених типова предлошког резултатива према лексичким групама; у ту сврху смо користили електронске корпусе. Семантичка обележја једне или друге конструкције не можемо посматрати одвојено од посебних обележја која се могу видети само приликом посматрања великог броја примера. Под таквим допунским обележјима подразумевамо расподелу и продуктивност. Постајемо свесни продуктивности када схватамо да преко 90\% свих појављивања предлошког резултатива у корпусима припада на лексеме које се у тој конструкцији јављају од једног до пет пута: круг лексема са великом учесталошћу је веома узак, а између високо- и нискофреквентних лексема практично нема прелазне зоне.

Као довољно поуздан показатељ продуктивности може да послужи коефицијент од укупног броја лексема које могу попуњавати валентност предлога и учесталости појављивања предлошког резултатива у дискурсу (= type/token ratio). Испоставља се да варијанте личне и безличне употребе треба разматрати посебно. Иако је у чешком језику безлични тип укупно гледано много чешћи него у пољском, у пољском је лексичка разноврсност приметнија у личној варијанти. Када је реч о безличном типу, коефицијенти types/tokens у оба језика много се мање разликују.

Кључне речи: резултатив, пољски језик, чешки језик, предлошке групе, импликатуре, метонимијска померања, расподела, лексичко пуњење, електронски корпуси. 